\title{
HETÊ BABETAN Û HUNERÊ EDEBÎYAN RA ANALÎZÊ MEWLIDÊ EHMEDÊ XASÎ
}

\author{
İlyas Akman*
}

\section{Kilmvate}

Mewlidê Xasî, edebîyatê Zazakî de esero nuştekîyo verin o. Her çiqas no mewlid, edebîyatê Zazakî de esero nuştekîyo verin bibo zî Xasî, pey hunermendîyeyê xo yo serkewte edebîyatê Zazakî, yew hemle de dekeno zereyê edebîyatanê serkewtan. Ma xebateyê xo de eserî, hetê babetan û hunerê edebîyan ra analîz kerd. Verî ma her beș ser cîya cîya vindertî û ma nawna ke beşan de kamcîn babetî est î. Xasî babetî ke sey xelqê Pêxemberî û eşyayan, xelqê Âdemî, Âdemî Cenet ra eştiş, zewacê maye û pîyê Pêxemberî, mucîzeyî ke Amîna ciwîyayî, bîyayîşî Pêxemberî, mucîzeyî ke roco Pêxemberî ameyo dinya de ameyî wucûd, nuzulê wehyî, hedîseyê Mîracî ra behs keno. Dima ra zî ma hunerê edebîyî ke mewlid de vêrenî tesbît kerdî. Ma veyna ke Xasî eserê xo de hunerê telmî', îktîbas, cînas, mecazo mursel, teşbîx, îstîare, teşxîs, întak, îstîfham, nîda, leff û neşr, îade, îştîkak, husnî talîl, asonans, alîterasyon, telmîh, tekrîr rê ca dono.

Çekuyê Kilîdî: Edebîyatê Zazakî, Ehmedê Xasî, Mewlid, Hunerê Edebî, Edebîyato Klasîk

\section{THE ANALYSIS OF EHMEDÊ XASÎ'S MAWLIID İN TERMS OF THEMES AND LITERARY ART}

\begin{abstract}
Ehmedê Xasî's Mawlid is the first written work in Zazaish/Zazaki literature. That is why, this work is very important for Zazas. Although this work is the first written work of Zaza literature, the author puts Zaza literature among the successful literatures with his own successful writing. I analyzed the work in terms of themes and literary arts in my article. Initially, I evaluated each section separately and show the themes in the sections. Xasî mentions subjects such as the creation of the Prophet and things, the creation of Adam, Adam's expulsion from heaven, The marriage of the Prophet's mother and father, the miracles that Amina experience, birth of the Prophet, the miracles that took place the night the Prophet was born, revelation, ascension. Then, I revealed the literary arts in the work. Xasî uses literary arts such as quotation, pun, metaphor, comparison, personification, question, repeat, alliteration, assonance.
\end{abstract}

Keywords: Zazaish/Zazaki Literature, Ehmedê Xasî, Mawlid, Literary Art, Classical Literature.

\footnotetext{
Makale Gönderim Tarihi: 15.02.2019, Kabul Tarihi: 05.04.2019

Doi: $10.26791 /$ sarkiat.527637

* Dr. End. Pwd., Unîversîteya Mardîn Artuklîyî, Fakulteya Edebîyatî, Beşa Ziwan û Edebîyata Kurdî, Mêrdîn, Turkîye, ilyas-akman@hotmail.com
}

ORCID ID: orcid.org/0000-0003-2146-2100 


\section{DESTPÊK}

Mewlidî, edebîyatê Rojhelato Mîyanênî de cayo muhîm gînî. Şaîrî ke Pêxemberî ra hes kenî û wazenî no hes kerdişê xo eşkera bikî tewirê mewlidî sey yew wasita veynenî. No tewir de zaf rey şaîrî welednayîşê, cuyê, mucîzeyê, herbê, ehlakê, merdişê Pêxemberî ser vindenî. Hedîseyê Mîracî û ameyîşê rîsaletî zî zaf mewlidan de xo rê ca veynenî (Pala, 2005: 312). Edebîyatê Zazakî de zî no tewir de eserî nusîyayî. Bira (hetta), esero verino ke Zazakî nusîyayo no tewir de yo.

Edebîyatê Zazakî de heya inkey (nîka) nê mewlidî nusîyayî:

1- Mela Ehmedê Xasî, Mewlidu'n-Nebiyyi'l-Qurayşiyyi (Salawâtullahi Aleyhi Fi'l- Bukreti we'l-Aşiyyi).

2- Osman Efendiyo Babij, Biyîşê Pêxemberî (Mewlûda Nebî).

3- Mela Mehmed Elî Hunij, Mewlidî Peyxemberî.

4- Mela Mehemedê Muradan, Mewlidî Zazakî.

5- Mela Kamilê Puexî, Mewlidî Nebî.

6- Bîlal-Feqî Çolîg, Mewlidê Peyximbêr Qey Tutonê Zazon.

7- Abdulkadir Muşekî (Arslan), Mevlid-i Nebî (Yergin, 2015: 102).

Ma xebateyê xo de mewlidê Xasî ser vindenî. La ma verî wazenî ke derheqê Xasî de toy malumat bidî. Bawkalê Xasî, Çewlîg ra bar kerdo ameyo Licê. No semed ra Xasî, Licê de maya xo ra bîyo. La ma tam nêzonî ke kamcîn ser ameyo dinya.

Toy cigêrayoxî vonî serra 1863 de (Malmîsanij, 1985: 75), toyî vonî serra 1866 de (Dağılma, 2015: 126) toy zî vonî serra 1867 de (Lezgîn, 2013: 4; Varol, 2012: 631) maya xo ra bîyo. O yew alîmo dînî yo. Licê de çend ser sey muftî xebatîyayo. Heto bîn ra o, yew muftîyo muxalîf o. Coka nefî beno erşawîyeno Rodos.

O eynî wext de yew nuştox o zî. Bira, seke ma va edebîyatê Zazakî de esero verin o nuseno. No eser, mewlidê ey o. Xasî no eser qeyê nuşto? Toy çimeyî vonî ke o, eserê xo yew xeberdayîşo ke benetî ey û mollayê Kurmancan de ameyo wucûd ser ra nuşto. Toy mollayê Kurmancan pey yarî (henek) Xasî ra vonî, edebîyatê nuştekîyê Kurmancan est o û ê, hetê kulturî ra aver şî. Ê dom kenî vonî la Zazayî, hetê kulturî ra tepa monayî; bira Zazayî wayîrê yew eserî zî nîyî. Nê qalan ser Xasî, xo qefelneno keye. Yew hefte keye ra nêvecîno û mewlidê xo nuseno. Badê, no mewlidî ano mollayê Kurmancan ver û vono "ho şima rê yew esero Zazakî" (Anter, 2000; Korkusuz, 2004).

Mewlidê Xasî, hetê edebî ra zaf serkewte yo. Xasî pey mewlidê xo edebîyatê Zazakî, resneno sewîyeyê edebîyatê bînan û yew hemle de edebîyatê Zazakî dekeno zereyê edebîyatê serkewtan. Eser hîcrî 1316, mîladî 1899 de neşr bîyo. No eser bi alfabeyê Erebkî nusîyayo. ${ }^{1}$ Xasî eserê xo de qalibê "Fâ'îlâtun, fâ'îlatun, fâ'îlun" şuxulneno. Qafîyeyê ci zî aa, bb, cc... yo:

\footnotetext{
1 Toy nuştoxan, mewlidî Latînîze kerdî. Verî 1985 de Malmîsanij; reya diyin, 1994 de Mihanî; reya hîrin, 2005 de Molla Mehamedê Kavarî; reya çerin, 2008 de W. K. Merdimîn; reya pancin, 2008 de Roşan Lezgîn; reya şeşin, 2016 de Osman Ozer metnî Latînîze kerdo. Ma xebateyê xo de metnê Ozerî şuxulna. Benetî alfabeya ke nuştoxî weçînaya û alfabeya ke ma weçînaya de toy herfan de ferqî est î. Mîsale nuştoxî herfê ı, ü şuxulnayî la ma nê herfî nêş̧uxulnayî. Heme maqele de girewtikî ke ma kitabê ey ra girewtî de ma tena numreyê rîpelî da. Nuştox, xebateyê xo de nê herfanê

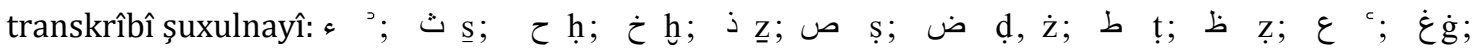
ق $\mathrm{k} ; \mathrm{j} ; \dot{\mathrm{\theta}} \mathrm{y}$
} 
“yev vakeyke/zerd ū yev sìm/hem sė pes

hem deṿey zi்/zey pesān dāy/ende bes

(a)

(a) $"(52)$

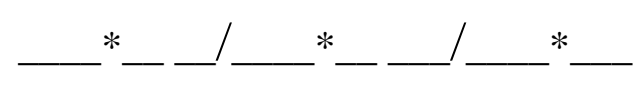

Fâ' î lâ tun/ Fâ' î lâ tun/Fâ î lun

Ma no xebateyê xo de cerebnenî ke eserî, hetê babetan û hunerê edebîyan ra analîz bikî. Coka verî ma her beş, hetê babetan ra tehlîl kenî. Dima ra zî hunerê edebîyî ke mewlid de vêrenî tesbît kenî.

\section{BEŞÊ MEWLIDÎ DERHEQÊ ÇINAYÎ DE Yî}

\subsection{Beşa Yewin}

Nuştoxî, zaf rey mewlidan de beşa yewin de ca donî hamdele, munacat. Mewlidê Xasî de zî no rewşe est o. No beş 21 beytî yo û no ca de Xasî rîyê xo tadono Homayî rê û medhê ey keno. No medh rey de o wazeno ke binawno însan çi ecz o û muhtacê rehmê Homayî yo. Xora o vono ke fexr û medh tena yê Homayî yo. Çî yo ke însan ganî biko, roc û şew her nefes de Homayî rê hemd û şukr kerdiş o. Çunke Homa, însanî xalk kerdo, ci rê çimî, destî, lingî û ê ezayê bînan da yî. Gore bi Xasî, ê kesî ke verê no lutfê Homayî ver de miskîn, kemî bibî ê, sey kerrayî hesan ke rûreş û zerresîyahî yî. La Xasî hewna zî însanan bêhêvî nêverdono. Nê qalan ra badê, hewna rehmê Homayî ano ziwan ser û vono xora Homa pey îlmê xo yo bêpeynî/bêhudud hemme çî veyneno:

"ger ebed yev ḥamdi tō ḳaṭ ni kerū

rạ̣meti tō ancī yō gō her berū" (34)

Seke aseno, Xasî vono ke însanî çendê nankorîye bikî zî Homa hewna înan ra rehmê xo kemî nêkeno. Xora Homa, heme çî veyneno. Ziwan bilasebeb xo betelneno. Coka însanî ganî verenî Homayî de milçewt vinderî û pawebê rehmê ey bibî. Badê Xasî, bala însanî anceno yewna hoke ser. Eke însanî, Homa ra hêvîyê xo bibirnî no yew çî yo xelet beno. Çunke tena şeytan Homayî ra bêhêvî yo. Însan ganî qet rîyê xo Homayî ra nêaçarno û timutim verê berê ey de bo. Heto bîn ra însanî, ganî pêxemberî zî xo vîr ra nêkî û timutim vacî "şāfīi i māzi muhammed mușțafā! ... / eș-ṣalāt ū ve’s-selām yā habīib” (34). Pey hes kerdişê Homa û Pêxemberî însanî resenî zerrîweşîye. Seke aseno, beşa yewin de hîna zaf hamdele, munacat est o. La toy zî bibo tevhîd û naat zî est o. Xasî, Homayî rê dest akeno. Ey medh keno û rehmê ey wazeno. Heto bîn ra vono ke Homa tena layiqê nê çîyano û no hewa tevhîdê ey tesdîq keno. Xasî, Hz. Mihemed ra zî vono Şafi‘ê ma. No hewa zî ca dono naatî.

\subsection{Beşa Diyin}

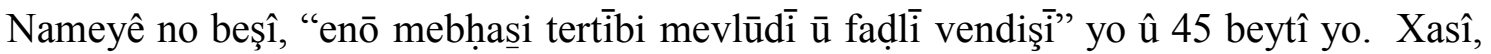
wazeno ke nawno ca ardişê mewlidî çi hewa bibo hîna baş o. Coka derheqê ca ardişê mewlidî de zaf malumat dono. Gore bi ey, verî însanî ganî tezyînê xo bikî û yew halo rind bidî xo. Badê muman, şerbet, buxûr, nan û sol bihedernî. Hedernayîşê nê çîyan dima, keyeyo ke mewlid dono gani merdimanê xo dawet biko. Xasî mewlidê xo de 
vono ke şewe mewlid dayîş hîna baş o. Çunke Hz. Pêxember şewe maya xo ra bîyo. Mewlid, semedê bîyayîşê Pêxemberî tanzîm beno. Coka ca ardişê mewlidî şewe bibo hîna rind beno. Nê malumatan ra badê Xasî, fedlê wendişê mewlidî ser vindeno:

"meclisā mevlūd biyō vendiş tede,

gō bıbō gàrḳ ey di nūr-i aḥmede" (36)

Gore bi Xasî, nûrê Pêxemberî cayo ke tede mewlid bîyo wendişî ser de vila beno. No nûr, ê cayî keno yew cayo nûrin, rind. Ê kesî ke mewlid goşdarî kenî, wanenî no zî sebebê mewlidî benî zî no nûr ra bara xo gînî. Ê se awa kewserî borî. Qebrê nê kesan zî asono. Ê persî ke milaketî qebr de înan rê persenî rê ê, ason cewab donî. Xasî badê, ca dono qalanê pîlanê dînî sey Hz. Ebubekîr, Hz. Omer, Hz. Osman, Hz. Elî. Nê qalî, derheqê fedlê wendişê mewlidî ser î. Xelîfeyan ra vêşêr, mewlid de qalanê sewbîna pîlanî dînî zî xo rê ca gînî. Mîsale Fexrê Razî vono ke kesî ke nonê mewlidî borî siudin î. Çunke no non, Homa ra efê nê kesan wazeno. Bira, gore bi toy kesan, cayo ke tede mewlid bîyo wendiş hînî Cenet hesebîyeno. Peynî de zî Xasî rexneyê însanan keno. Vono ke însanî kor û bêhed î. Coka însanî qedrê mewlidî nêzonî.

\subsection{Beşa Hîrêyin}

Nameyê no beşî, "enō mebḥași çınibiyāyişi eşyān ū sırr-1 humā yō" yo û 16 beytî yo. No beş de Xasî verî vono ke ewwel de Homayî ra vêşêr çîyêk çinî bi. Ne erd ne asmên bi. Însanî tena ney, hama ne cinî ne perî bî. $\mathrm{O}$ wext de mefhûmê wextî û cayî zî çinî bi. Ne wext, ne ca, ne şew û roc bi. Xasî zono ke hêşê însanan no rewşe ver de têmîyan kuweno. Coka vono ke wa însanî xo bîlasebeb nêbetelnî. Gore bi ey, eqlê însanî awe û herrî ra virazîyayo û no eql nîşno (nêeşkeno) hukmê şahê ekberî bitemam fam biko. Xora herf û sewtî zî nîşnî merîfetê Homayî bîyarî ziwan ser:

“çünkī ḥaddi ḥarf ū șavtān ḳaṭ niyō,

sırr-1 hallāḳ-i cihān yī ỵāciyo" (40)

Ne eql ne herfî̀ ne ziwan ne zî sewtî şînî (eşkenî) pîleyî homayî teswîr bikî. Ê sey roşnê çira yî. Çi hewa ke roşnê çira nîşno hukmê rocî sist biko, ê zî nîşnî sirrê, merîfetê Homayî bitemam terîf bikî. La manayê no çî eno nîyo ke însan, merîfetî homayî qet fam nêkeno. Gore bi vatişê Xasî, ehlê qelbê muhreqî şînî cuzêkê sirrê Homayî fam bikî.

\subsection{Beşa Çerin}

Xasî no beşî rê no name poneno: "Enō mebhassi ḩalk-i peyġamberi mā ū halḳ̣-i eşyānū." No beş 29 beytî yo. No ca de wendox/goşdar verî, nûrê/ruhê pêxemberan çi hewa xelk bîyo bonder beno. Homa tewr verî dara yekînî virazeno. Çer şaxê no dare est î. Badê Homa, nûrê xo ra toy gîno û pey o nûr, ruhê Pêxemberî xelq keno. Nê çîyan ra dima Homa, na dare ser zikrê ey keno. Zikrî ra dima yew lîlik (eynik) yeno wucûd. Wexto ke nûrê Pêxemberî lîlik ra eks beno, lîlik heya keno. Pey kelecanê no rewşe o ereq erzeno. Pey çilkê nê ereqî toy çîyî yenî meydan. Gul û birinc nê çîyan ra yî. Xora no beş de behsê xelqê eşyan zî beno. Babeta xelqê eşyan ra dima hewna behs tadîyeno derheqê Pêxemberî. Ruhê ey, panc rey Homayî rê secde keno. Gore bi Xasî, panc farzê Îslamî ewte ra yenî. Badê Homa, des û di hîcabê nadirî xelq keno: "Merhemet", "Keramet", "Minet", "Menzîlet", "Nubuvet", "Ta'et", "Se'adet", "Rif'et", "Hîdayet", "Te'zîm", "Şefa'et", "Qudret." Nê çî erjeyê xo Pêxemberî ra gînî:

"bacde cū nūr-i habīibi serverī, 
mendu her gō perdede yō çend șarī” (41)

Nûrê Pêxemberî, perdeyê nê des û di çîyan ser de muhletêk vindeno. Benetî înan de geyreno. Peynî de o, se zereyê yew uman ra vecîyo a hewa beno û ey ra çilkî kuwenî war. Verî, ey ra se hezar û di sey û çer çilkî kuwenî. Her gu çilkî benî ruhê yew pêxemberî. Badê, ey ra hewna çilkî kuwenî war. No rey zî nê çilkan ra ummetê ey xelq beno. Homa, nûrê Pêxemberî ra cewherêk zî virazeno. Badê, no cewher ra ewnîno û cewher di ca beno. Nêmeyê cewherî ra kef û dû yeno meydan. Kef, erd beno. Tewr verî zî Mekke virazîyeno. Du zî asmênî rê wucûd beno. Nêmeyê bînê cewherî ra zî sewbîna çîyî virazîyenî.

\subsection{Beșa Pancin}

Nameyê no beşî, "enō mebhași emr-i humā yō ḳey ḳaleme” yo û 17 beytî yo. No beş de xeberdayîşê Homa û qelemî est o. Homa, qeleme ra toy çîyan wazeno û qeleme zî verê nê çîyan de ecêb monena. O, qeleme ra vono ke "nuştiş bike!" Qeleme nê qalan cadê emir telakî kena û ey ra vona çi binuso. Homa tewr verî vono ke ey ra teber çîyêk çinî yo. La badê îlawe keno vono $\mathrm{Hz}$. Mihemed qasidê ey o. Wexto ke qeleme, nameyê Homa ra vêşêr yewna name hesnena cadê şona secde. A, yew çî zaf meraq kena: Hz. Mihemed kam o? Çunke Homa, reya verina ke yew name, nameyê xo rey de telafuz keno. Qeleme nîşna verê kelecanê xo de serkewte vecîyo û Homa ra persena ke bonder bibo Hz. Mihemed kam o? O, zî no cewab dono:

"hāālḳi ṿā evvel ū āhir ezā

yō zē maḥbūbı mınu ‘āşı̣ ezā” (43)

Qeleme, pey no cewabe bonder bena ke a, estbîyayîşê xo deyndarê Hz. Mihemed a. Hz. Mihemed keso ke Homa semedê ey heme çî xelq kerdo yo. Bira, Homa ey ra vono "mehbubê mı." No beş de sewbîna babetan ser de zî qalî vacîyenî. Mîsale, Homa vono kesî ke eksê emrê ey nêkî o, înan rê mukafat dono. No mukafat zî Cenet û wechê Homayî veynayîşo. Homa, bitaybetî semedê ummetê Hz. Mihemedî mizgînêk dono. Xora o, qeleme ra vono ke semedê ummetê ey surûr (şa bîyayîş) binuse. No beş de wendox/goşdar raştê "îla yewmîl-qîyame" zî beno. Yanî qeleme çîyî ke heta qiyametî do bibî nusena. Heme çî levhî mehfûz de nusîyayo.

\subsection{Beşa Şeşin}

Xasî no beşî rê no name poneno: "Enō mebhasasi halḳ-i ādemiyū nūr-i peygamberi yō kevti pāştī yí." No beş 40 beytî yo. No ca de verî wendox/goşdar bonder beno ke Âdem senê hewa xelq bîyo. Homa veng dono milaketan û înan ra wazeno ke ê, şeştî tewir herrî erd ra bîyarî. La o, înan ra yewna çî wazeno. Gore bi no waştiş, ganî herran de heme rengî bibî. Çunke Homa wazeno însanî seypê nêbî. $O$ wazeno însanî tewir bi tewir bibî. Milaketî heme herran anî û Cebraîl înan yew ca de roneno. Badê zî awayê rehmetî ser keno û ecelneno. La herrî yewbînan nêtepşenî, cîya cîya monenî. Cebraîl nê çîyan ra dima, behrê huznî ra toy awe, herran ser keno. Herrî, pey awe huznî yewbînan ra dusenî. Pey no herre, şeklê Âdemî virazîyeno. Badê, Cebraîl puf keno û Âdem ruh gîno. Senê ke Âdemî rê ruh dekeno o, warzeno û roşeno. Heme milaketî verê ey de secde kenî. Badê zî heme milaketî pey ey de vindenî. Âdem semedê no çî merax keno. Homa ra persono ke qeyê milaketî peyê ey de vindenî. No cewab gîno:

"ḩālıḳị̣ā nūri şāhi cinn ū ins 
hāv dī pāştey tōde yō eyrū celīis"” (46)

No beș de behsê sewbîna babetan zî beno. Mîsale, qeyê desto rașt hîna efdal o ser vindirîyeno. Wexto ke Âdem hama Cenet de yo, nûrê Homayî, gişta eşhedê Âdemî rê nazil beno. Coka desto raşt hîna efdal o û muslumanî gama ke nenguyanê xo kesnenî destê raşt ra dest pêkenî. Heto bîn ra Xasî vono ke Homa, însanan ra wazeno ke ê, ganî ehlê sebrî bibî. Bira, Homa vono eke însanî sebrê kerîm nêkî o, înan rê huzno ezîm dono. Kesî ke wayîrê sebrî bibî zî ê, ehlê îman î. No beş de behsê nûrê çer xelîfeyan û qeyê selam dayîş sunet o ser de zî vindirîyeno.

\subsection{Beşa Hewtin}

Nameyê no beşî, "enō mebḥași eştişe ādemi yō cennet $\bar{u}$ mārdiş-i

kālikān-i

peyġamberi mā" yo û 22 beytî yo. Ewta de Xasî wendoxan/goşdaran rê verî nawneno ke Âdem senê hewa Cenet ra erzîyayo. Verî vacîyeno ke Âdem û Hawa Cenet de xemilîyaye û şa yî. Homa înan ra vono ê, Cenet de heme çî kerdiş de azadî la tena yew çî înan rê qedexe yo: Nêzdî yew dare şîyayîş û fêkî aye werdiş. La ê, no emrî nêanîca û fêkê ci wenî coka Homa înan Cenet ra erzeno:

$$
\begin{aligned}
& \text { "bac de cū kū ādemī biemri kerd } \\
& \text { hālıḳi ỵā yì bigīiri berzī ard" (48) }
\end{aligned}
$$

Wexto ke Âdem û Hawa bêemrî kenî, Homa cigrîno û înan bêcilan erzeno erd. Erd de roc û şew fixan kenî. Hende bermenî ke pey hesrê înan darî û çereyî zergûn benî. Her gu roj xetayê xo qebul kenî û Homa ra efê xo wazenî. La Homa, xeylî wext goş nêdono înan. Rocêk Âdem, asmên ra ewnîno û nameyê Hz. Mihemedî veyneno. Na rey pey nameyê Hz. Mihemedî efê xo wazeno. Homa qa xetrê Hz. Mihemedî înan ef keno. No efî ra pey Xasî, mewlidê xo de na rey kalêkanê Pêxemberî ser vindeno. O vono, nûro verin paştê Hz. Şîs (Şît)î de vecîyeno. Badê no nûr, eyelanê înan de dom keno. Xasî vono o, heme nameyan nîşno vaco. Çunke belkî yew xeletîye biko. La vono, Hz. Ednanî ra dima bêşik nameyan şîno vaco. Nê nameyen rêz keno: Ednan, Me'd, Nîzar, Muder, Îlyas, Mudrîke, Xuzeyme, Kenan, Nedr, Malik, Fehr, Xalib, Luey, Ke‘b, Murre, Kîlab, Qusey, Ebdulmenaf, Haşim, Ebdulmuttelib. Xora nameyê pîyê Hz. Mihemedî zî Ebdullah o. No hewa Xasî vono ma şînî bêşik vacî ke şecereyê Hz. Mihemedî de 21 kesî est î.

\subsection{Beşa Heştin}

Xasî no beşî rê no name poneno: "Enō mebḥasi 'abdullahi yō cühūd-i şāmiyānū ù vāştış1 āminā ciri." No beş 28 beytî yo. No beş de verî wendox/goşdar, raştê kesî ke wazenî pîyê Hz. Mihemedî Ebdullahî bikişî yeno. Wexto ke nûrê Hz. Mihemedî, pîyê ey Ebdullahî de zuxur keno, kafirî fam kenî ke ameyîşê Pêxemberî nizdî yo. Coka wazenî, verê bîyayîşê Pêxemberî, pîyê ey bikişî. Kafirî, hama şinikeyê ey ra heme ca de ey geyrenî. Rocêk hewtay kesî (Xasî vono, ê Cihud î) yenî têhet û sond wanenî ke ganî ey bikişî. Ê kesî Şam ra wardenî û Ebdullahî dima şonî. Bi taybetî şewe, rayîr ra şonî. $\hat{E}$ bira, dorê Mekke şonî û toy kesan casûsê xo kenî. Rocêk yew casûs xeberêk ano ke Ebdullah tena şîyo çolêk. Ê sey vergê haran şonî ke ey bikişî. La wexto ke ê resenî ey, eskerê rewhanîyanî asmên ra yenî war. Nê eskerê Homayî, Cihudan tar û mar kenî. No beş de babeta diyin, derheqê zewecîyayîşê Ebdullah û Amîna de yo. Pîyê Amîna, Weheb, wexto ke Ebdullahî veyneno cadê nûro ke ey de yo ferq keno. $\mathrm{O}$ wext bire/qerar dono ke keynaya xo Amîna bi do ey: 
"gō bidī yī ger bıbō yīrā ḳabūl

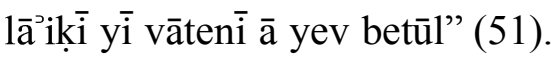

Weheb vono, Ebdullah keso ke layiqê keynayê ey bigî yo. O verî şono keyeyê xo û no bireyê xo înan ra vono. Badê zî şono pîyê Ebdullahî, Ebdulmuttelîb, het û ey ra vono ke o, wazeno keynaya xo bido lacê ey. Ebdulmuttelîb şono no xeber Ebdullahî ra vono. No xeber Ebdullahî de tesîro pîl virazeno. Her di hetî zî qayîlê no zewacî benî. Hetê Ebdullahî şonî Amîna wazenî. Gore bi edetan keyeyê Amîna, se pesî, se deweyî û toy zî zerd û sîm wazeno. Badê heme çîyan veyveyê înan, aşma Recebî de yew şewê îne de ronîyeno.

\subsection{Beşa Newin}

Nameyê no beşî, "enō mebḥași intiḳāli nūr-i peyġamberi yō ū hevnān-i āminā ū" yo. No beş 27 beytî yo. Beş de hîna zaf, hedîseyî ke maya Pêxemberî Amîna ciwîyayî ser vindirîyeno. Wexto ke nûrê Hz. Mihemedî Amîna rê eks beno a, serebutanê metafîzîkan ciwîyena. Nûrê Pêxemberî aye şa keno û aye rê erje dono. Gama ke Amîna diganî bena, hewnanê rindan veynena:

"yev şevike ez di hevni kev şirīn

mın dī āme merdümi kev enverīn" (52)

Aşma verinê diganîyîye de, yew rocê aşma Recebî de Hz. Âdem şono hewnê aye. O, hewn de nameyê "Mihemed" fekê xo ra veceno û Amîna ra selam keno. Aşma diyin de, yew rocê aşma şebanî de na rey Şis (Şit) pêxember hewn de aye ra aseno û aye ra selam keno. Aşma hîrin de Îdrîs pêxember hewn de aye ra aseno. Aşma çerin de Nûh pêxember aye ra selam keno. Aşma pancin de Hûd, aşma şeşin de Îbrahîm, aşma hewtin de Îsmail, aşma heştin de Mûsa, aşma newin de Îsa pêxemberî şonî hewnê aye û aye ra selam kenî. Nê hewnan ra vêşêr, mewlid de sewbîna babetan ser de zî vindirîyeno. Înan ra yew mergê pîyê Pêxemberî, Ebdullahî yo. Wexto ke Amîna bena şeş aşme, Ebdullah semedê bazirganîye/tîcaret şono bajaranê bînan. Gama ke reseno Medîne nêweş beno. $\mathrm{O}$ hama vîst û panc serre yo û weyra no nêweşî ra mireno. Gore bi vatişê Xasî, no mergî ra dima der û ber, heme heywanî bermenî.

\subsection{Beşa Desin}

Nameyê no beşî, "enō mebḥasii velednāyişi peyġamberi māvu șallallahü caleyhi ve calā ālihi ve sellem" o û 18 beytî yo. No ca de Xasî, Hz. Mihemed senê hewa maya xo ra bîyo, ameyo dinya ser vindeno. Wexto ke aşma rebîul-ewwelî ra des şewî şonî, Amîna xerqê nûrî bena. Manayê ci no yo ke bîyayîşê Pêxemberî hînî nêzdî yo. Raşta zî gama ke duyêsê rebîul-ewwelî beno, Pêxember maya xo ra beno. O wext, hedîseyê metafîzîkî zî benî. Çer hebî cenî, yenî Amîna rê ardim kenî: Meryem, Sara, Asîya, Hawa. Nê cenîyê mubarekî xîzmetê Amîna kenî. Hem zî no xîzmetî bêqusur kenî. Bi no hewa, erjeyê Pêxemberî eşkera beno. Wextê xelesîyayîşî de Amîna qet ezîyêt nêancena. Wexto ke a, teyşan bena zî aye ra yew şerbeto sey gulab anî. Amîna vona ke ne şeker ne zî engemîn sey no şerbetî şîrin nîyo. Badê şimitişê şerbetî, canê Amîna rehet beno û yew teyre zî yena bonê aye. Badê zî Pêxember teşrîfê dinya keno:

“tāỵili mın dī habīibi mın emīn

āme dünyā ḳūmū ḳavme’l-ḥażı̄īn” (55) 
Ameyîşê Pêxemberî ra dima însanan ra vêşêr, heme çî yeno zîwan. Heme eşya û heywanî ey rê selam kenî. Eyra nê çîyan vanî: Ti xeyr ameyî "seyyîdel kewneynî, sirrê subhan, rûhê rûhan, fexrê "erşî, sahîbel dînîl mûbîn." Na beş de Xasî, toy îfadeyano Erebkî rê zî ca dono. Înan ra toyî nê yî: "Merheba ya qurrete "eynîl wera / Merheba ya men nubî'te fîl Hîra."

\subsection{Beșa Yewendesin}

Nameyê no beşî, “enō mebḥasi henī cacāyibānu āmey vücūd şevī mevlūdī” yo û 17 beytî yo. Xasî verî wazeno nawno ke Pêxember, çende zaf ummetê xo rê ehemîyet dono. O vono, gama ke o maya xo ra bi, cadê Homa rê secde keno û badê zî semedê ummetê xo Homayî ra şefaat wazeno. Pêxember vono o, semedê xo çîyêk Homayî ra nêwazeno. $\mathrm{O}$ vono ummetê ey aciz o û semedê ci nîyaz keno. Nê malumatan ra dima Xasî, bala wendoxan/goşdaran anceno hedîseyî ke şewa Mewlidî de amey wucûd. Tewr verî behsê adirê Mecusîyan keno:

“ādırì yine çerāy nībi çīi $\bar{i}$

lā-şevey mevlūdide yō bī çīini”' (57).

Adirê Mecusîyan, henzar serrî timutim veşeno û qet hewn ra nêşono. Xora Mecusîyî, adirperest î (Özkan, 2016: 30). La şewa Mewlidî de no adir çin beno. Hedîseyo diyin, derheqê yew qesr de yo. No qesr, wayîrê vîst û yew estune yo. La şewa ke Pêxember maya xo ra beno, des û çer hebî estunê ci kuwenî war. Hedîseyo hîrêyin, a şewe behrê Sawa zuwa beno. Xasî nê mucîzeyan ra vêşêr behsê yew cihudî zî keno. No merdêmo cihud, perseno ke a şewe kam gede ameyo dinya. Ey ra vacîyeno ke gedeyê Ebdullahî bîyo. O cadê vono ke wazeno gedeyî veyno. Ey rê Pêxemberî anî. Wexto ke o Pêxemberî veyneno vono o, pêxembero peyin o û nameyê zî Ehmed Mihemed hem Emîn o. O îlawe keno vono, dîno ke o ano, dînanê verinan batil keno.

\subsection{Beşa Diwêsin}

Xasî no beşî rê no name poneno: "Enō mebḥași halīmā-yı sa diyānu raḍıyallahu ta ālā 'anhā.” Beş, 24 beytî yo. No ca de hîna zaf behsê Helîma ya ke şitê xo dayo Pêxemberî beno. Verî yew mucîze beno. Amîna, hewnê xo de veynena ke Helîma şit dona lacê aye. Benetî ra toy wext vêreno û yew karwan yeno Mekke. No karwan, semedê gedeyanê şinikan yeno. Ê, Mekke ra toy gedeyan benî û xo het çend serrî mikat kenî. Helîma zî zereyê no karwan de ya. Helîma, Pêxemberî weçînena. Yewna lacê Helîma est o. Nameyê ey Dumrete yo. Wirdî pîya şitê Helîma şiminenî. Wexto ke Mekke ra tepa ageyrenî, her kes ecêb moneno. Çunke herê Helîma zaf şehtîyaye yo û edetî (normal) de nîşno lez têgeyro. La wextê ageyrayîşî de no her ser de hîrê kesî est î ew hewna zî heme heran vêreno. Wexto ke her veyneno her kes ecêb monayo, pey îznê Homayî destpêkê xeberdayîşî keno:

“çünkì nıştu mın muhammed żü’l-'alem

yō kō ḳey yī halḳ bıbì ‘ arş ū ḳalem” (59)

Xeberdayîşê herî ra dima her kes narey ecêb mendişê diyin ciwîyeno. Reya verino ke veynenî yew her xeberî dono. Bira, toy kesî vonî gelo no yew xîyal o? Badê resenî keyeyanê xo û Helîma heta Pêxember beno hîrê serre ey miqat kena. Benetî nê serran de a, yew rey zî necaset nêveynena. Pêxember yew gedeyo pak o. Badê Helîma, Pêxemberî tepa bena dona Amîna. La wexto ke Pêxember şeş serre beno, Amîna zî mirena. A ra dima, Ebdulmuttelîb yanî bawkalê Pêxemberî, wayîrê ey vecîno. La di serrî ra dima o zî mireno û datê Pêxemberî na rey ey gîno binê hîmayeyê xo. 


\subsection{Beşa Hîrêsin}

Nameyê no beşî, “enō mebḥasi nuzūl-i vaḥy ū mi rāciyō” yo û 51 beytî yo. Xasî verî wazeno nawno ke Pêxember Homayî ra çende zaf heskeno. Pêxember timutim vono ke semedê ey, Homayî ra vêşêr çîyêk çinî yo. O, şew û roj derheqê Homayî de fikirîyeno û zereyê xo de şikrê ey keno. Sewbîna çî zî est o: Pêxember zono ke rocêk, ey rê asmên ra çîyêk yeno. Pey nê fîkran, rocêk hewna şono koyê Hîra û weyra hedîseyê metafîzîkan ciwîyeno. Nişke ra Cebraîl vecîyeno yeno û ey rê wehîya verin ano: "Îqre bîsmî." O, çewres serre yo û pêxembero pêyin beno. No roc ra bedê Cebraîl, şew û roc ey rê wehîyanê neweyan ano. No hewa benetî ra diwês serrî vêrenî û wextê Mîracî yeno. 27ê Aşma Recebî de Cebraîl, pey emrê Homayî şono Pêxemberî het û ey ra vono ke Homa wazeno ey huzurê xo de veyno. Pêxember cadê pey awa zemzemî xusul gîno û nimac keno. Dima zî verî şono bi Qudus. Heme Pêxemberî, milaketî û cinî weyra întîzamin hedre yî û pawebi ey î. Pêxember şono verenî, beno mela û pîya nimac kenî. Nimacî ra dima Pêxember, Cebraîlî rey de şono asmên. Heme sirrî ey rê ayan benî. Wexto ke resenî Sîdre (Sîdretü‘l Müntehâ), Cebraîl vono eke o, weyra ra aver şo veşeno. Coka Pêxember tena Sîdre ra vêreno. Weyra o, Homayî veyneno:

"dī cemāli yì di rey reyb ū şek

lā-belì ninā ebed ỵātış bi fek" (64)

Pêxember di rey, Homayî ra ewnîno. La Xasî vono ke, fek nîşno wesfê Homayî bido: "ḳaṭ yenī nuştış bıbì baḥr-i hubur?" (64). Qur'an de no ayet est o: "Semedê nuştişê qalanê Homayî, behrî murekeb bî û hende qas zî îlawe bikî, verê qedîyayîşê qalê Homayî, behrî peysenî” (Sureya Kehf, 109). Xasî no ayetî rê telmîh keno. Badê Mîracî Pêxember, tepa şono Mekke. Yew serre weyra vindeno û dima hîcret keno şono Medîne. Weyra zî des serrî vindeno û emrê ey yeno şeştî hîrê.

\subsection{Beşa Çarêsin}

No beşê dua yo û 11 beytî yo. Ewta Xasî Homayî rê dua keno: Haza Du'aû Mewlidin Nebîyî. O, verî wazeno nawnoke însanî çi eczî. Coka vono ke ma însanî, kemterîn û qasir î. Heto bîn de zî rehma Homayî ra vono "zaftir" o. O vono însanî, asî û şermende yî. La hewna zî ê, mîyanê xewfî Homayî de yî. Xasî zono eke Homa, fîlê însanan ra biewnîyo, felatê însanan ason nîyo. Coka no beş de timutim xo erzeno binê rehmê Homayî. Vono ke dergahê Homayî ra vêşêr yew ca çinîyo ke însanî şê weyra. Pey nê cumleyen rehmet wazeno:

“tı bi ḥaḳki ḥurmeti nāmey hū ke

mā fakīì ū bī kesān mahrūm meke" (65).

No beș kılm o û hîrê beytê peyinî bi Erebkî nusîyayî. Nê beytan de Xasî vono, roco hesabî de mala (înşalla) teksîratê însanan ef bibo. Yew peynîye yo rind wazeno. Vono ke bê rehmê Homayî ne o ne zî tu kes şîno raro raştî veyno û bifeletîyo. Peynî de zî semedê heme ruhê Muslumanan fatîha wazeno.

\subsection{Beşê Ê bînî}

Beşa çarêsin ra dima Xasî, ca dono yewna beş. La nameyê no beşî çinî yo. Ewta vono ey, pey ardêmê Xaliqî û Pêxemberî no mewlid nuşto. Ewta, nameyê xo sey "Xasî Hezanic" îfade keno. Derheqê nuştışê Mewlidî de toy malumatan dono. Vono, benetî "kaf'ê Erebî û "kaf"ê sewbîna ziwanan de ferq est o. Coka Mewlid de "kaf"ê sewbîna ziwanan ser hîrê nuqta ronayo û "kaf"ê Erebî de hîrê nuqtay nêronayo. No beş ra bedê 
beşa “Haza Nezmu’t -Tarîxî Lî Muellîfî'l-Mewlidî” yeno. No beş, seraser bi Erebkî nusîyayo. Derheqê tarîxê nuştişể Mewlidî de yo. Xasî vono ke ey, no Mewlidî, mamosteyê ci Hecî Îbrahîmî het serra 1316 yê hîcrî de nuşto. Peynî de zî gore bi hesabê ebcedî tarîxê 1316 nuseno. Bedê beşa "Eyzen Lî Muellîfîhî̀" yeno. Yew beyt o û bi Erebkî nusîyayo. Ney ra dima hewna nameyê "Eyzen Lî Muellîfîhî" nusîyeno. No beş zî yew beyt o la bi Zazakî nusîyayo. Ewta Xasî vono ey, heme babetê rindî weçînayî û pey înan Mewlidê Mihemed Ehmedî ardo wucûd. Dima ci, beşa "Haze't-Teqrîzu Lî'l'Ellametî's-Su'erdi'l-'Umerîyyî Fethîllah Hesbî’' (Lezgîn, 2013: 54) yeno. No teqrîz hetê Fethullah Hasbî yo ke Sêrtij o ra nusîyayo û bi Erebkî yo. Ewta Fethullah Hasbî, wesfề Xasî û Mewlidê ey dono.

\section{MEWLID DE HUNERÊ EDEBî}

\subsection{Ebced û Tarîx Fînayîş}

Hesabê ebcedî de, herfan rê numreyî dayîyenî. No hewa, herfan ser ra yew sîstematîk virazîyeno. Wextê verinan de edîbî, tarîxnasî, merdimê fermî no hesab şuxulnayêni. No hesab ra hesabê cummel, ebîcad, ebucad zî vacîyeno (Elker, 2006: 19). Verî toy nuştoxî, peynîyê eseranê xo de pey no hesabî nawnayêni ke eserê xo key nuşto. Xasî zî peynî Mewlidê xo de no hesab şuxulneno: فَأَتْهَدْتُ حَتْماً هاهُنا باَبَ أَبْجَد (66). Ma inkey, no îfade ra nizdî ra bewnî.

$$
\begin{aligned}
& \text { 400 =790 }
\end{aligned}
$$

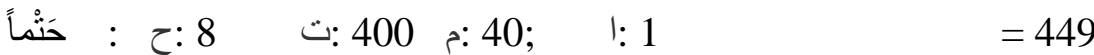

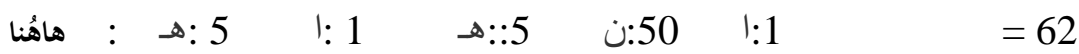

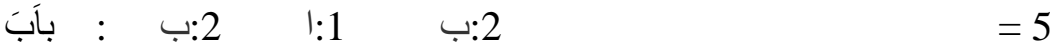

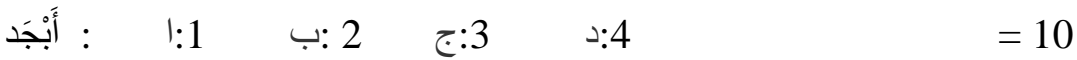

Pêro pêser: 1316

Eke ma no îfadeyo Erebkî, herf bi herf analîz bikî ma şînî biresî tarîxo ke Mewlid nusîyayo. Seke ma nawna, heme herfî rê yew numre kuweno û pêserkerdişê nê numreyan zî ma rê tarîxê nuştişê Mewlidî dono. Xasî, pey no îfadeyo Erebkî nawneno ke eserê xo hîcrî 1316 ( mîladî 1899) de nuşto.

\subsection{Telmî'}

Hunerê edebîyan ra yew zî telmî' o. Eke nuştoxî, yew rêza beytî sewbîna ziwanî de binusî telmî' beno. Ge-ge zî nuştoxî, heme rêzî ney leteyêkê rêzî sewbîna ziwan de nusenî û telmî' virazenî (Kocakaplan, 2005: 149). Xasî zî eserê xo de muracatê no hunerî keno:

$$
\begin{aligned}
& \text { “iy zi yāatu yev hadīisi kev nefīs } \\
& \text { men aḥabbeni huve "ind-i celīs" (38) }
\end{aligned}
$$

Xasî, muracatê yew hedîsî keno. La gama ke no hedîsî nuseno nişke ra ziwan bedelneno. Rêza yewin de wendox mîyanê dinyayê Zazakî de yo. La wexto ke wendox çimê xo beno rêza diyên ser, na rey xo dinyayê yewna ziwanî de veyneno. Na rey Erebkî, hawsalayê wendoxî gîna binê bandura xo. No ca de zî eynî çî est o:

"kerd ū ỵātu yā muḥammed ya emīn

$$
\text { أَنْتَ مِنِّي رَحْمَةًَ لِلْعالَمِينَ }
$$


Seke aseno, Xasî rêza diyêni seraser Erebkî nuşto. Rêza yewin Zazakî yo û rêza diyên de ziwan bedelîyeno. Xasî hîna zaf weqto ke muracatê ayet, hedîs û dua keno hunerê telmî' şuxulneno. Beyto ke cêr de yo zî de telmî' est o:

$$
\begin{aligned}
& \text { "ỵā bınūsne ümmetey yīî̄ sürūr } \\
& \text { ümmetün müznibetün rabbün gafūr" (44) }
\end{aligned}
$$

No beş de Homa, qeleme rey de xeberî dono. Aye ra vono ke ummetê Pêxemberî rê şa bîyayîş binuse. La emro diyin de ziwan bedelîno. Zazakî cayê xo Erebkî rê verdono. Zafê wendox zî no ca de fam kerdişî vindî kenî. No îfadeyo Erebkî ra dima hewna Zazakî destpê keno. La wendox badê hewna raştê Erebkî yeno:

$$
\begin{aligned}
& \text { "bī müferreh ỵā bì ilhāme rabbī }
\end{aligned}
$$

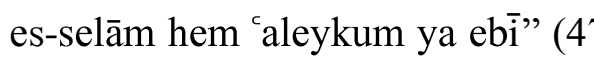

Beyto diyin Erebkî nusîyayo. La, wendox zafê çekuyî ke na rêze de vêrenî zono. Coka fam kerdişê na rêzî de zaf zehmet nêonceno. La rêzê badêyî ke tede hunerê telmî' est î hende ason nîyî. Semedê wendoxê Zazayan fam kerdişê nê rêzan zehmet o:

"ỵā dī āşmey hevti ismā̄î̀l zebīh

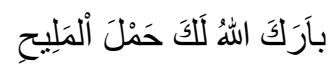

āme āşmey heştī musā ḳey mı ỵā

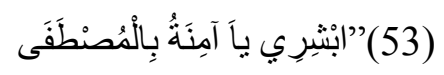

No beş de wendox, bonder beno ke wextê diganîyeyê Amîna de her aşme, yew pêxember yeno zîyaretê aye. Aşma hewtin de Îsmail şono aye het û neql keno ke Homa vono diganîyeyê aye mubarek biki. Aşma heştin de zî Musa şono aye het û diganîyeyê Amîna pîroz keno. No beyt de zî telmî' est o:

"hem niyāz kerd $\bar{u}$ du'āyı hem ricā

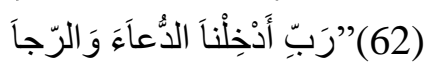

Xasî verî behsê duayê Pêxemberî keno. Pêxember, wexto ke şono Mîrac, verî nêmacêk keno. Nêmac ra dima zî dua keno. Xasî zî Homa ra wazeno, o û însanî bînî zî daxîlî a dua bibî. Rîpelanê badêyan de zî kê raştê telmî’ yenî:

"hāalıḳi perde vedārut ū ṿā emīn

$$
\text { (64) }
$$

Mîrac de Pêxember, asmên de geyreno. Weyra zaf çîyan veyneno. O, Homayî zî veyneno. Homa, perde wedarneno û Pêxemberî ra vono wa ey ra biewnîyo. La Pêxember, verî sereyê xo hawanênono. Naye ser Homa, ey ra vono sereyê xo hawani. Nê rêzan de zî telmî' est o:

$$
\begin{aligned}
& \text { "tāỵili ỵendāci hallāḳi verā }
\end{aligned}
$$

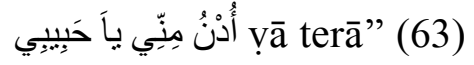

$$
\begin{aligned}
& \text { "vaḳtu 'avvul bī haber-dār yev nezīir } \\
& \text { yā hemā allahuekber mın kebīir" (59) }
\end{aligned}
$$


Seke ma verî zî vatibi, ge-ge nuştoxî heme rêzî ney leteyêkê rêzî sewbîna ziwan de nusenî. Xasî telmî' yo ke no hewa virazîyeno zî şuxulnayo. Cor de ma toy mînakan dayî. Heme mînakî ke ma dayî nawnenî ke Xasî, hunerê telmî' eserê xo de zaf şuxulnayo.

\section{3. Îktîbas}

Edebîyatê klasîkî de nuştoxî, çimeyê dînî ra zaf îstîfade kenî. Eserê klasîkan de hem ayetî hem zî hedîsî, cayê muhîm gînî. Eke nuştoxî, eseranê xo de ca bidî ayet no zî hedîsî rê, no îktîbas beno (Aktaş, 2002: 131). Nuştoxî ge-ge toy leteyanê ayet û hedîsî ge-ge zî heme îfadeyê ayet û hedîsî gînî dekenî zereyê rêzanê xo. Bitaybetî eserî ke muhtewayê înan derheqê babetê dînan de yî de hunerê îktîbasî zaf est o. Mewlid, no tewiran ra yewo. Xasî zî Mewlidê xo de hem ayetan ra hem zî hedîsan ra îstîfade keno:

$$
\text { “eṣ-ṣalāt ū ve’s-selām yā ḥabīib” (34) }
$$

Xasî no îfade, yew ayet ra girewto. Qur'an de na sure est a: "Ey kesî ke îman kerdî! Şima zî ey rê selat bikêni, selam bikêni" (Sureya Ahzab, 56). Wextê verînan ra heya inkey însanî, semedo ke no ayet nîşan bidî, vatişê "es selatu wes selam" şuxulnenî. Homa wazeno ke her kes Pêxemberî rê selat û selam biko. Xasî, Mewlidê xo de hem ca dono no ayet hem zî çîyo ke ganî biko keno û Pêxemberî rê selat û selam keno. Îktîbaso bîn no yo:

$$
\begin{aligned}
& \text { “iy zi ȳâtu yev hạadisi kev nefīs } \\
& \text { men aḥabbeni huve "ind-i celīs" (38) }
\end{aligned}
$$

Gore bi yew hedîs, Pêxember vono ke kam ey ra hes biko Cenet de ey reyde beno. Coka zaf şaîrî ke ey ra heskenî, eseranê xo de ca donî no hedîs û waştişê xo Homayî ra vonî. Xasî zî Mewlidê xo de behsê no hedîs keno. Bira, hedîs ra vono "nefîs." Yanî Xasî estbîyayîşê no hedîs ra zaf şa yo. Çunke zono eke o, Pêxemberî ra hes biko Cenet de ey rey de beno. Xasî, na rêze de Erebkî şuxulneno. No ca de zî îktîbas est o:

$$
\text { " (56) }
$$

No beyt, ayeta 107. yê sureya Enbîya ra girîyayo. No ayet de Homa vono ey, Pêxemberî aleman rê sey rehmet erşawito. Xasî zî Mewlidê xo de behsê no ayetî keno. Na rêze de zî îktîbas pey yew hedîs virazîyeno:

$$
\begin{aligned}
& \text { “ṿā bınūsne ümmetey yīî̉ sürūr } \\
& \text { ümmetün müznibetün rabbün gafūr" (44) }
\end{aligned}
$$

Yew Hedîs te vacîyeno ke Cenet de her pelan ser de no îfade nusîyeno: Ummetun muznîbetun Rebbun xefûr (Bursevî, 2010). Xasî Mewlid de ca dono no hedîs zî. Manayê ci no yo: Ummet gunekâr o; Homa ef kerdox o. No beyt de Homa, qeleme ra vono ke o, ummetê Pêxemberî rê şa bîyayîş wazeno. Coka qeleme ra vono no çî binusi. Na rêze de zî ayet ra îktîbas est o:

"ārde iḳra bismi ḳalbi yīde ṿā" (61)

Nuştox pey îfadeyê "îkra bîsmî” sureya Alakî ra îktîbas kerdo: "Îkra' bîsmî rabbîkellezîy Xalak" (sureya Alak, 1). Pêxember rocêk şono eşkefta Hîra û weyra ey rê wahîy nuzul beno. wahîya yewin pey "îkra bîsmî" destpê keno. Xasî zî Mewlidê xo de no behs ser vindeno û wahîya yewin ra îktîbas keno. Yewna îktîbas no yo: 


\section{“tāỵili ṿendāci hullāḳi verā

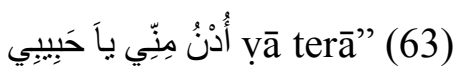

No rey sureya Nemcî ra îktîbas bîyo. No sure de nê qalî est î: Badê, ey rê nizdî bi. Xo da o het û hîna nizdî bi (Sureya Necm, 8). Gore bi zaf alîman no ayet, derheqê Mîracî de yo. Mewlid de zî Xasî vono Homa, Pêxemberî ra Mîrac de vono mi ra hîna nizdî bi.

\subsection{Cînas}

Şî̂r de çekuyî ke hetê veng û formî ra eynî no zî yewbînan ra nêzdî la hetê mana ra yewbînan ra cîya bişuxulî no cînas beno (Kocakaplan, 2005: 24). Xasî zî Mewlidê xo de çend tewir cînas şuxulneno. Înan ra yew Cînaso Lahîk o. Eke çekuyan ra tena yew herf cîya bibo no cînaso lahîk o. Beytê ke cêr de yî de no tewir cînas est o:

“eṣ-ṣalāt ū ve's-selām yā ḥabīb

dā’imā tōrū bı̣̣āri yā tabīib" (34)

"yev bıdō yev dirheme bi ḳalbu şedīd

zey di bedr ū hem huneynde bō şehīd" (37)

"heybetān rā bıdi şaḳḳı secde berd

ba di secdi ṿā çıyācī rabbu ferd” (44)

"hem dì hevni bì hisāâi nādirī

ger biȳi ṿātış bi emr-i ḳādirī̄” (53)

“ey geli ‘’ạkil tamām $\bar{u}$ cālìyān

mā çı zāni ḳadr-i dürr-i gāaliyān” (54)

"baḥr-i sāvā zuvā bī yevzì ā şevì

ev tede nì mende aṣlā yev hevī" (57)

"sac diyān vaḳtu ḳu dī hükmi herī

bī muhayyer vạa ḥalīmā rā ṿerī” (58)

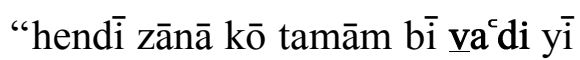

yev resūl aṣlā çınìkō ba ca di yîi” (61)

“hem ciri bī à cemī'-i züu'n-nikạāb

hā çì cennet hā cehennem hā ‘ikāāb" (62)

"dī cemāli yī di rey reyb ù şek

lā-belī ninā ebed yāâtış bi fek” (64) 
Seke aseno Xasî, Mewlidê xo de cînaso lahîk rê zaf ca dono. Pey nê cînasan hetê ahengî ra eserê xo hîna serkewte keno. Mewlid de sewbîna cînasî zî est î. Înan ra yew Cinaso Mutaraf o. No cînas de çekuyan ra yewî de yew herf hîna vêş o. Yanî yew çekuye, zereyê çekuya bîn de ya:

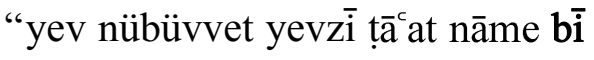

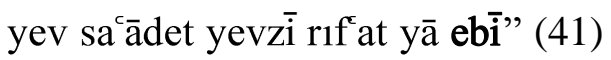

$$
\begin{aligned}
& \text { "vaḳtu bì şeş āşme ḥamli ey cirī } \\
& \text { kerd 'abdullahi ḳaṣdi ticirī” (54) } \\
& \text { "vā zerey min bìi dīnīmì vey lımın } \\
& \text { hālıḳ̂i yerdā yetīm nō ḥamli mın” (54) } \\
& \text { “çünkī pāştey yī ser ū nūru'l-enām } \\
& \text { yī bızāni her zìi ya fūr bì bi nām” (58) }
\end{aligned}
$$

Nê mînakî zî eşkera kenî ke Xasî, cînaso mutarafî̀ zî şuxulneno û wazeno pey no hunerî ahengê eserê xo pêt biko.

\subsection{Mecazo Mursel}

No hunerê edebî de yew çekuye, yewna çekuye ver şuxulîyena. Ristimê na çekuya Erebkî "ce-ve-ze" ra yeno û manayê ci "cayê vîyartişî no zî raro vîyartişî̀" yo (Eliaçik, 2013: 39). No huner de çîyo tewr muhîm, ganî benetî çekuyan de munasebetê yewbînan monayîş çinîbo. Benetî çekuyan de munasebetî sey ca-rewşe, lete-pêroyî, taybetmendîpêroyî, semed-netîce, toyîye-zafîye, zere-teber usb est î. Xasî zî eserê xo de ca dono mecazo mürselî rê:

$$
\begin{aligned}
& \text { "hem bi hū zānāyina yō hāāli niyō } \\
& \text { gō ciri 'azmānī rā çìike biyō" (60) }
\end{aligned}
$$

Xasî vono ke Pêxemberî zonayêni ke o tena nîyo, yew ey paweno. Coka o, timutim pawebi yew çî yo. Pêxember pawebi wahîyî yo. Coka Xasî vono o, asmên ra çîyêk paweno. Bi eslê xo de Pêxember Homayî ra çîyêk paweno. Yanî Xasî Homayî ver ra asmên vato: Asmên = Homa. Benetî çekuyan de munasebetê ca-rewşe est o. Na rêze de zî mecazo mursel est o:

$$
\text { “ārde iḳra bismi ḳalbi yīde ỵā" (61) }
$$

Xasî gama ke sureya Alakî ra yew ayet gîno, heme ayet rê ca nêdono. Ney ver yew leteyê sureyî gîno: Îkra bîsmî = Sureya Alekî ra yew ayet. Benetî çekuyan de munasebetê lete-pêroyî est o. La wendox no lete ra fam keno ke Xasî behsê sureya Alekî keno. No beyt de zî mecazo mursel est o:

$$
\text { "mā bi fek ta rīif bıker hem medhi yī" (36) }
$$


Însanî gama ke çîyêk terîf kenî ziwanê xo şuxulnenî. La no ca de Xasî vono ke ma pey fekî terîf bikî. Her çiqas o fek vaco zî qesdê ey ziwan o: Fek = Ziwan. Benetî çekuyan de hem munasebetê lete-pêroyî hem zî zere-teber est o. Yanî yew mecazo mursel o pêt o. Yew mecazo mursel zî ewta est o:

“şì keye ỵā kiye hū rā ḥāl ū ḥevāll” (51)

Wexto ke Zazayî benetî xo de qalî kenî ge-ge semedê cenî û eyelan çekuya keye şuxulnenî. Mîsale vonî "keye û kulfetî senênî?" Mewlid de zî no hewa yew îfade est o: Kîye $=$ Cenî û eyelî. Benetî çekuyan de munasebetê ca-însan est 0 . No beyt de zî kê şînî mecazo mursel veynî:

"rabbi ḥāli mā bi hū tō rā cāyān

lāzımey hendī çiyā yāâcu zıvān" (34)

Xasî ewta vono halê însanan eşkera yo. Yanî Homa xora heme çî veyneno. Coka hewce nîyo ke însanî halê xo Homayî ra vacî. La Xasî însanî ver ra çekuya ziwanî şuxulneno: Ziwan= Însan. Her çiqas o ziwan vaco zî qesdê ey însan o. Însan halê xo vono ziwan ney. Benetî çekuyan de munasebetê lete-pêroyî est o. Beyto cêr de zî no huner est o:

“linge eşte zengü ey ḩayrü’l-enām” (62)

No ca de Xasî derheqê Mîracî de toy çîyan vono. Pêxemberî se kerdo senê hewa têgeyrayo ser vindeno. La seke cor de zî aseno ge-ge nameyê ey nêvono. Ney ver "xeyrul-enam" vono: Xeyrul-enam = Hz. Mihemed. Mewlid de ge-ge zî semedê ey "xeyrul-beşer" vacîyeno. Pey nê îfadeyan mecazo mursel virazîyeno. No ca de zî no huner est o:

“ḩālıḳi yerdā yetīm nō hạamli mın" (54)

Amîna, wexto ke pêhesîna mêrdeyê aye merdo zaf xemgîn bena. Cadê lacê ey Hz. Mihemed yeno vîrê aye. Zona ke o hînî yew yetîm o. La seke rêze de zî aseno nameyê Hz. Mihemedî nêvona. Ney ver vona "hemlê min". Coka ewta zî mecazo mursel est o. Ewta zî no huner est o:

“caḳli ḥayvānī ebed ỵer pī meke” (39)

Beşa ke na rêze tede vêrena de Xasî, behsê sirrê Homayî keno. O, pîlîyeyê Homayî ser vindeno. Sifetê Homayî çinayî înan vono. Ge-ge zî nameyê Homayî ney sifetê ey vono. Rêza ke cor de yî de zî no çî keno: Ebed = Homa. Yanî raştaraşt Homa nêvono. Ney ver yew sifetê Homayî ebed (beka) ano ziwan ser. Benetî çekuyan de munasebetê taybetmendî-pêroyî est 0.

\subsection{Teşbîx}

Teşbîx de di çîyî ke yewbînan monenî est î. Nuştox vono çîyo sist, çîyo pêt/hêzin ra moneno. Teşbîx de çer unsurî est î: Muşebîh (benzeyen), Muşebîhun bîh (kendisine 
benzetilen), Hetê şibnayîşî (benzetme yönü), Edatê teşbîxî (Benzetme Edatı) (Lezgîn, 2017: 55; Çetin, 1998: 203). Kê Mewlidê Xasî de zî raştê no hunerî yenî:

"ḥāli miskin ū faḳīi ū nāḳiṣān

rū reş ū zerre siyāhi zey hesān" (33)

No beyt de teşbîxo mufasal est o. Teşbîxo mufasal de heme unsurê teşbîxî est î. Xasî vono ke halê miskîn, feqîr û naqisan sey hesanî rîreş û zerresîya yo. No beyt de unsurê teşbîxî nînanî: Muşebîh: Miskînî, feqîrî, naqisî; Muşebîhun bîh: Hesan; Hetê şibnayîşî: Rîreş, zerresîya; Edatê teşbîxî: Zey. No beyt de zî eynî teşbîx est o:

"āme cazmānrā cühūdī tār ū mār

kerdī pìr ù eşti şī yīzey gubāro" (51)

Vacîyeno cihudî sey xubarî vila benî, tar û mar benî. No ca de heme unsurê teşbîhî est î. Coka teşbîxo mufasal o. Unsurê teşbîxî: Muşebîh: Cihûdî; Muşebîhun bîh: Xubar; Hetê şibnayîşî: Tar û mar; Edatê teşbîxî: Zey. No ca de zî Xasî eynî teşbîx şuxulneno:
"bac di cū teyşān biyā ez bī hisisāb
min dì āme şerbeti kev zey gül-āb
lā-belì nì şekker $\bar{u}$ ni engmīn

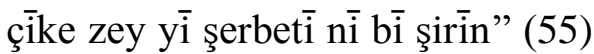

Weqto ke bîyayîşê Pêxemberî nêzdî beno, Amîna toy mucîzeyan veynena. Cenîyî mubarekî sey Meryem, Sara, Asîya xîzmetê aye kenî. Yew wext yeno Amîna teyşon bena. A game aye rê yew şerbeto ke gulab moneno dayîyeno. A vona ke no şerbet engimên û şeker ra şîrênêr o. No beyt de unsurê teşbîxî nînanî: Muşebîh: Şerbet; Muşebîhun bîh: Gulab; Hetê şibnayîşî: Şîrên; Edatê teşbîxî: Zey. No beyt de zî teşbîx est o:

“şeyh baṣrī ỵātu zey kūh-i uhud

zerdi mā bi gō di yev mevlūd de bıd" (37)

No beyt de, teşbîxo muxtasar est o. Teşbîxo muxtasar de hetê şibnayîşî nêvacîyeno. La hewna zî wendox, zono ke qesdê nuştoxî çinayo. Beyto ke cor de yo de Şêx Basrî vono sey koyê Uhudî zerdê ey bibî zî hewna zî tipinî mewlid de dono. Qesdê Şêx Basrî zafîyeyê Zerdan o. La o, ney nêvono. Unsurê teşbîxî: Muşebîh: Zerd; Muşebîhun bîh: Koyê Uhudî; Edatê teşbîxî: Zey; Hetê şibnayîşî́-. Beyto ke cêr de yo de zî teşbîx est o:

$$
\begin{aligned}
& \text { “yō ‘aḳl kū aṣlı yī āvev hạāi } \\
& \text { ‥ } \\
& \text { gō bıbō zey meşk perçe āy bırā" (39) }
\end{aligned}
$$

Vacîyeno eqlê însanî, meşke perçe moneno. La kum hetra yewbînan ra monenî nêvacîyayo. Coka teşbîxo muxtasar o. La wendox fam keno ke Xasî vono, eqlê însanî verê sirrê Homayî de ecz o, bêqiymet o. Unsurê teşbîxî: Muşebîh: Eqlê însanî; Muşebîhun bîh: Meşke Perçe; Edatê teşbîxî: Zey; Hetê şibnayîş̧î-. Ewta zî teşbîx est o:

“mā huūri ỵātı enō her gō direy 
de bımānō nişkenu biyor ū çırey

mā di enkā ỵineni zey yev gazāl

meş kenu reyrā bi emr-i lā-yezāl” (59)

Helîma wexto ke şona Mekke, herê aye zaf sist o. Yew hero şehtîyaye yo. La Helîma, semedê miqat kerdişî Pêxemberî gîna û pîya wenişenî herî. No her, narey zaf lez û weş şono. Xasî vono sey xezal rara şono. La tam nêvono sey xezal lez û weş şono. Coka teşbîxo muxtasar o. Unsurê teşbîxî nînanî: Muşebîh: Her; Muşebîhun bîh: Xezal; Edatê teşbîxî: Zey; Hetê şibnayîşî̀-. No beyt de zî teşbîx est o:

“tāyilì ānyā kū ḳalbi yì hemān

bì ze rōc vaḳtu yenō miyāni çımān" (61)

Xasî vono wehya verin de qelbê Pêxemberî sey rocî beno. La tam nêvono sey rocî roşn bi. No semed ra teşbîxo muxtasar o. Unsurê teşbîxî nînanî: Muşebîh: Qelb; Muşebîhun bîh: Roc; Edatê teşbîxî: Ze; Hetê şibnayîşî-. Beytî ke cêr de yî de zî tewirê teşbîxî est î:

$$
\begin{aligned}
& \text { "kevti çolū kerbelā-yı kāfirī } \\
& \text { şi hatattā dūri mekkī zey ādırì } \\
& \cdots \\
& \text { vaḳtu di kevti dımā zey ỵergi ḩār } \\
& \text { şi biyī berh-i civānī hey hevār" (50) }
\end{aligned}
$$

Beyto yewin de teşbîxo muxtasar est o. Vacîyeno kafirî sey adir î. La kum hetra yewbînan ra monenî nêvacîyayo. Hewna zî wendox fam keno ke kafirî zaf hêrsbîyaye yî. Unsurê teşbîxî neyî: Muşebîh: Kafirî; Muşebîhun bîh: Adir; Edatê teşbîxî: Zey; Hetê şibnayîş̂î-. Beyto diyin de teşbîxo mufasal est o. Vacîyeno kafirî sey vergê har î. No ca de heme unsurê teşbîhî est î. Unsurê teşbîxî nînanî: Muşebîh: Kafirî; Muşebîhun bîh: Verg; Edatê teşbîxî: Zey; Hetê şibnayîşî: Har. No ca de zî teşbîx est o:

$$
\text { “küfr-i dünyā kerd bī şev bī gümān” (36) }
$$

Na rêze de vateyo mecazî est o. Xasî vono ke kufr, hende zaf bibi ke dinyayî sey şewe tarî kerdebi. Ewta manayê şewe menfî yo. Yanî yew kes, şewa tarî de nîşno rarê xo weş veyno coka timutim gamanê xeletan erzeno. Gore bi Xasî kufr, dinya no hewa yew ca keno. Kufr, heme ca ra roşn wedarneno û tu kes nîşno raro raşt/rarê heqqî veyno. No ca de teşbîxo belîx zî est o. Teşbîxo belîx de edatê teşbîxî û hetê şibnayîşî nêvacîyenî. Unsurê teşbîxî nînanî: Muşebîh: Dinya; Muşebîhun bîh: Şewe; Edatê teşbîxî:-; Hetê şibnayîşî́-. Yew teşbîxo belîx zî ewta est o:

$$
\begin{aligned}
& \text { "sèrrì saḳți vật cāv mevlūd tede } \\
& \text { vāneni yō cennetu yì hāy tede" (38). }
\end{aligned}
$$

Nê rêzan de vacîyeno ke cayo ke tede mewlid wanîyeno sey cenetî rind o, mubarek o. La çekuyê rind û mubarekî nêvacîyenî. Edatê teşbîxî zî nêşuxulîyeno. Unsurê teşbîxî: Muşebîh: Cayo ke tede Mewlid wanîyeno; Muşebîhun bîh: Cenet; Edatê teşbîxî:-; Hetê şibnayîşî̀-. Nê beytan de zî teşbîx est o:

“çünkī ḥaddi ḥarf ū șavtān ḳaṭ niyō

sırr-1 ḩallāḳ-i cihān yī ỵāciyo 
$\cdots$

ḩāṣılī ḳat eşkeni rūşeni çırā

hükmi rōcì sist kerū hüukmi hū rā" (40)

Nê beytan de di hebî teşbîxo belîxî est î. Xasî vono herf û sewtî, sey roşnê çira sist î. Eksê ney zî, sirrê Homayî sey hukmê rocî pêt o. La beytan de heme unsurê teşbîxî ca nêgirewtî. Unsurê teşbîxî nînanî: Muşebîh: Herf û sewtî, sirrê xellaqê cîhanî; Muşebîhun bîh: Roşnê çira, hukmê rocî; Edatê teşbîxî:-; Hetê şibnayîşî-.

\section{7. Îstîare}

Îstîare hetêk ra teşbîx moneno. Îstîare de zî di çî yewbînan monenî. La tena no muşebîh no zî muşebîhun bîh şuxulîyeno. Eke tena muşebîh bibo no îstîareyo meknî (kapalı istiare) yo. Tena muşebîhun bîh bibo zî o wext îstîareyo musaraxa (açı istiare) beno. Edebîyatê klasîkî de nuştoxî no huner zaf şuxulnenî (Demir, 2009: 70). Mewlidê Xasî de zî mînakê îstîareyî est î:

“çünki şev bī āme şāhi enbiyān" (35)

Na rêze de îstîareyo musaraxa est o. Xasî vono ke Hz. Mihemed, benetî pêxemberan de sey şah o. La nameyê Hz. Mihemedî rêze de nêvêreno. Tena nameyê muşebîhun bîh vêreno. Xasî Mewlid de toy cayan de semedê Homa zî vono şah:

“yō 'aḳl kū aṣlı yī āvev haraì

yō çı zānu hü̈kmi şāhi ekberī” (39)

Xasî semedê Homayî vono "Şaho Ekber". La nameyê Homayî rêze de nêvono. Tena nameyê muşebîhun bîh vêreno. No hewa îstîareyo musaraxa virazîyeno. Sewbîna beytan de zî o, semedê Homayî vono şah: "pī bızāni pīliyey āy şāhı mā" (36). Xasî semedê Amîna zî vono şah:

"bac de cū şī yī bi curfi āy zamān

vāşte ‘abdullahi ri şāhi cihān” (52)

No ca de zî kê raştê îstîareyo musaraxa yenî. Xasî vono Amîna, şahê cîhanan monena. La nameyê Amîna rêze de nêvêreno. Tena nameyê muşebîhun bîh vêreno. Na rêze de zî eynî huner est o la tena Amîna ra sultan vacîyeno: "tōri müjdeyānı bi sulțān-i verā" (53). No beyt de zî îstîare est o:

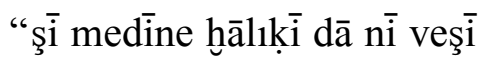

ḳaybi 'abdullahi şerbet verduşī" (54)

No beyt, derheqê merdişê Ebdullahî de yo. Ewta semedê merdişî, şerbet werdiş vacîyeno. La nameyê merdişî beyt de nêvêreno. Coka no zî îstîareyo musaraxa yo. Semedê merdişê Ebdulmuttalîbî, nê qalî vacîyenî:

"ḳabri ri meymān bī cabdu’l-muțtalib" (60)

Na rêze de semedê mergî, meyman bîyayîş vacîyeno. La nameyê mergî rêze de nêvêreno. Tena nameyê muşebîhun bîh vêreno. No semed ra ewta zî îstîareyo musaraxa est 0 . 
Mewlidê Xasî de hunerê teşxîs û întakî zî xo rê ca veynenî. Gore bi toy çimeyan teşxîs û întak zî zereyê îstîareyo meknî (kapalı istiare) de yî. Coka kamcîn ca de teşxîs û întak est o weyra îstîareyo meknî zî est o (Demir, 2009: 75). Ma cêr de behsê teşhîş û întakî kenî. Nê cayan de îstîareyo meknî zî est î.

\subsection{Teşxîs û Întak}

Nuştoxî ge-ge heywanan, nebatan û çîyê êbînan sey însanan veynenî û nê çîyî sey însanan têgeyrenî. No teşxîs o. Eke nê çî sey însanan xeberî bidî o wext zî întak beno. Nê hunerî zaf rey pîya şuxulîyenî. Mewludê Xasî de nê hunerî est î:

"pīze dekūnān bıko cūş ū țarab

gō bıvāz ū tım cafū ỵācu ā rabb

āy kō ez ver dā gunehkār $\bar{u}{ }^{c}$ afū

vāzenā ìri bi nāmey tō ‘afū" (37)

Nê beytan de nan, sey însanan têgeyreno û xeberî dono. Tewr verî ma veynenî ke yew kelecanî ci girewto. Pîzeyê însanan de zaf şa yo. Yanî sey însanan têgeyreno. No teşxîş o. Badê destpêke xeberdayîşî keno. No zî întak o. Nan, Homayî rey de xeberî dono û efê însanan wazeno. Beytê ke cêr de yî de zî nê hunerî est î:

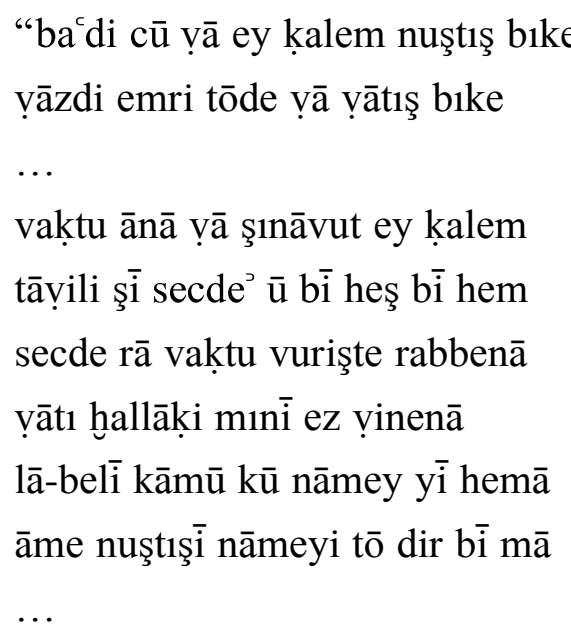

heybetān rā bıdi şaḳ̣ı secde berd

ba di secdi ỵā çı̣̣ācī rabbu ferd " $(43,44)$

Nê beytan de qeleme, hem sey însanan têgeyrena hem zî xeberî dona. A vona ez emrê Homayî de yo. Verê Homayî de secde kena. Badê, verê yew çî de ecêb monena. Ewnîna ke nameyê Homayî het yewna name est o. No name Mihemed o. A, Homayî ra no name persena. Homa aye ra vono, derheqê ummetê Hz. Mihemedî de toy çîyan binuso. Gama ke qeleme nê çîyan nusena yew gome vindena. $\mathrm{O}$ wext Homa aye ra vono "bes teeddub ya qalem! (bişermaye!)" Pey nê qalan qeleme şeqîyena. Seke aseno beytan de hem teşxîs hem zî întak est $o$. Na rêze de zî teşxîs est o:

"gō bibō derg nō kitābu nāzenīn" (53)

Nazenîn bîyayîş hîna zaf semedê însanan vacîyeno. La Xasî kitabî ra vono nazenîn. Pey nê îfadeyan o, hunerê teşxîsî şuxulneno. No beyt de zî eynî huner est o: 
“dār $\bar{u}$ ber pīi $\bar{u}$ tedir bermāy bi ḥāl

hem çị̀āa ḥayvānī der sehl ū cibāl” (54)

Hama ke Amîna diganîyîye de bena şeş aşme, pîyê Pêxemberî Ebdullah semedê bazirganîye/tîcaret şono toy bajaran. Wexto ke reseno Medîne weyra nêweş beno û weyra no nêweşî ra mireno. Xasî vono, heme heywanî û nebatî no merdiş rê bermenî. Beytî ke cêr de yî de întak est o:

"ỵā caceb minde memān-i sa diyān

ez binişsiklì eger şī āsimān

çünkì nıştu mın muhammed żü'l-'alem

yō kō ḳey yì halk bıbi 'arş ū ḳalem

eyrū pāştey mın bi hū efḍal tırā

māsivā rā bāş bızāni ey verā" (59)

Helîma şitê xo dona Pêxemberî û ey miqat kena. Wexto ke Helîma şona Mekke, semedê Pêxemberî bîgo, yew hero zaf şehtîyaye aye de est o. No her lez nêşono. Helîma Pêxemberî gîna û pîya agêyrenî. La na rey her, zaf lez şono. Bira, tu her nîşno reso ci. Herkes no rewşe rê ecêb moneno. Her, no rewşe fam keno û pey emrê Homayî destpêkê xeberdayîşî keno.

\section{9. Îstîfham}

Ristimê no hunerî pers o. Nuştoxî derheqê toy çîyan de persan persenî û no hewa îstîfham yeno wucûd. No proses de edatê persî şuxulîyenî (Kocabıyık, 2017: 649). No huner de malumato newe pawitiş mecburî nîyo. Bira, zaf rey nuştoxî, çîyî ke ê cewabanê zonî persenî. Yanî armancê înan çîyêk bonderbîyayîş nîyo. Ê wazenî, kelecanê xo eşkera bikî û wendoxan zî dekî yew kelecan. Mewlidê Xasî de zî no huner est o:

"key yenō cā rabbi ḥaḳki şükri tō" (33)

Xasî, beşo ke na rêze te de vêreno de medhê Homayî keno. O, eczîyetê însanan zî nawneno. O vono, heme çî Homa ra yo û ganî însanî zî Homayî rê şikr bikî. La însanî her çiqas şikr bikî zî hewna zî nîşnî heqqê lutfê Homayî bidî. Coka o vono însanî ebed ra heya ezel zikrê Homayî bikî gelo heqqê şikrê Homayî ca yeno? Her çiqas seke Xasî bêrsiv nêzono biaso zî o zono ke no mumkîn nîyo. No beyt de zî îstîfham est o:

"yō kū hallāḳ-i cihān-1 medḥi yī

kerdu mā hendī çı vāàn vaṣfı yī” (36)

Xasî derheqê Pêxemberî de xeberî dono. Wazeno wesfê ey bido. Badê yeno vîrê ey ke Homayî, medhê Pêxemberî kerdo. No semed ra gore bi ey, hînî hewce nîyo ke sewbîna kesî bicerebnî ke wesfê Pêxemberî bidî. Yew îstîfham zî ewta est o:

"bes niyō hendī çı yāei āy fetā" (38) 
Xasî no beş de vono, ê însanî ke mewlid donî wendiş û Pêxemberî ra hes kenî şonî Pêxemberî hetî. O vono no çî ra baş yewna çî çinî yo û coka sewbîna qalan rê hewce çinî yo. Na rêze de zî îstîfham est o:

“mā çı zāni ḳadr-i mevlūdī binās” (38)

No beş de, hîkmetê mewlid waneyîş ser vindirîyeno. Kesî ke mewlid wanenî, kesî ke mewlid donî wendiş, cayo ke te de mewlid yeno wendiş û ê çîyî bînî ke derheqê mewlidî de yî medh benî. Xasî no hewa cerebneno ke qedrê mewlidî bido çiman ver. La hewna zî vono ke ma qedrê mewlidî nêzonî. Ewta zî îstîfham est o:

$$
\begin{aligned}
& \text { “yō ‘aḳl kū aṣlı yì āvev harāi } \\
& \text { yō çı zānu hüikmi şāhi ekberī” (39) }
\end{aligned}
$$

Rêzanê verinan de Xasî derheqê însanî de toy qalan vono. Gore bi ey însan, awe û herrî ra virazîyayo û zaf hetan ra noqsan o. Coka însan, nîşno hukmê Homayî tam fam biko. Beyt de semedê însanî çekuya eqlî şuxulîyeno. Beyto ke cêr de yo de zî îstîfham est o:

$$
\begin{aligned}
& \text { “ḩāṣılì ḳaṭ eşkeni rūşeni çırā } \\
& \text { hükmmi rōci sist kerū hükmi hū rā } \\
& \text { caḳl ū hararf ù ṣavṭi māzi yō ḳader } \\
& \text { eşkeni sırrān bi fek biyāri teber” (40) }
\end{aligned}
$$

Xasî vono herf û sewtî, sey roşnê çira sist î. Eksê ney zî, sirrê Homayî sey hukmê rocî pêt o. Coka herf û sewtî nîşnî sirrê Homayî tam bîyarî ziwan ser. Eynî hewa, eqlê însanî zî nîşno sirrê Homayî tam fam biko. Coka eql zî mîyanê eczîyetî de yo. Sirrê Homayî eql, herfan û sewtan ser de yo. Nê rêzan de îstîfham est o:

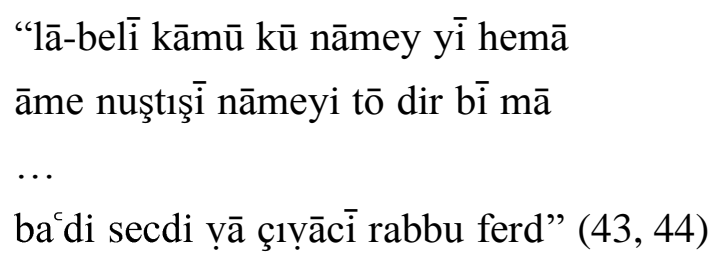

Wexto ke Homa qeleme ra vono ke nameyê Hz. Mihemed binusne, qeleme ecêb monena. Çunke Homa reya verina ke nameyê xo het de yewna name roneno. Coka a, nameyê Pêxemberî Homa ra persena. Wextê nuştişî de yew game qeleme vindena. Naye ser Homa veng dono qeleme rê. Qeleme verê Homayî de secde kena û emrê Homayî pawena. Ewta zî îstîfham est o:

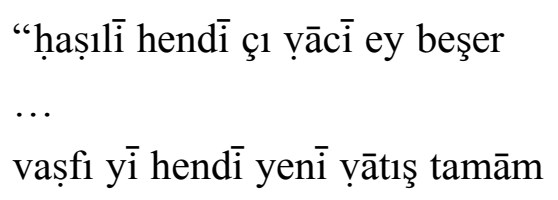


Nê rêzan de vacîyeno ke medhê Pêxemberî zî zaf ason nîyo. Pêxember şono Mîrac û Homayî veyneno. O, no hewa çîyî ke tu qulê Homayî nîşno veyno muşahede kerdo. Homayî zaf sirrê xo nawnayî ey. Gore bi Xasî, Pêxember hende însano pîlo ke çew nîşno tam wesfê ey bido.

\subsection{Leff û Neșr, Îade, Îștîkak}

Hunerê edebîyan ra yew zî leff û neşr o. Manayê çekuya, pêser ardiş û vilakerdiş o. No huner de şaîrî rêza yewin de toy çekuyan şuxulnenî. Eke rêza diyin de çekuyî ke derheqê çekuyanê rêza yewin de vêrenî de yî bişuxulnî no leff û neşr beno. Eke rêz kerdişê nê çekuyan de yew întîzam bibo, no leff û neşro muretteb o. Eke întîzam çinî bo no zî, leff û neşro muşevves beno (Haşıc1, 2010: 20). Xasî no beyt de muracatê no hunerî keno:

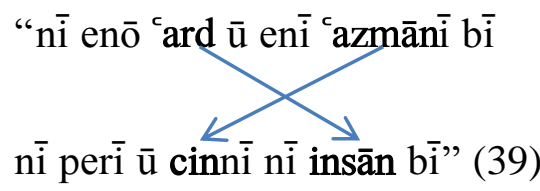

Seke aseno, rêza yewên de çekuyê "erd û asmên" vêrenî. Rêza diyên de zî çekuyî ke derheqê înan de yî yanî "cin û însan" vêrenî. Însanî erd de, cinî zî hîna zaf asmên de ciwîyenî. La Xasî nê çekuyan întîzamin rêz nêkono. Yanî verî kombînasyonê "erdînsan” nêkeno. Coka ewta leff û neşro muşevves est o. Xasî hunerê îade zî şuxulneno.

Eke nuştoxî, pey çekuya ke pêynî rêza yewin de ya, rêza diyên destpê bikî no îade beno. Wendox, eserê xasî de zî raştê no hunerî yeno:

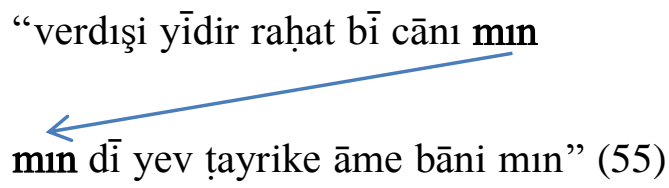

Rêza yewên pey çukuya "min" qedîno. Rêza diyên zî pey no çekuye destpê keno. Xasî pey no beyt, hunerê îade rê yew mînak dono.

Yew beyt de no zî rêze de eke çekuyî ke eynî ristim ra yî pîya bibî no huner ra îştîkak vacîyeno. Mewlidê Xasî de kê raştê no hunerî yenî:

"hem muhammed mürsel ū mürsil ezā" (48)

Na rêze de çekuyê "mursel" û "mursîl" eynî ristim ra yenî. Wirdi zî ristimê "resel" ra yenî wucûd. Rêza ke cêr de ya de zî eynî huner est o:

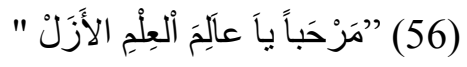

Çekuyê "alîm” û “îlm” ristimê “ "lm ” ra virazîyayî. No semed ra ewta zî îşîikak est o. Seke mînakî zî nawnenî Xasî, hunerê leff û neşr, Îade, Îştîkak zî eserê xo de şuxulneno

\subsection{Nîda}


Ge-ge şaîrî dekuwenî mîyanê kelecanî. Ê wextan de şaîrî, çîyî ke verê ey de yî rê xîtap kenî. Nameyê no hunerî nîda yo. Zaf rey pey înterjeksîyonanê (unlem) sey ey, vax, ya, eyvax, eya virazîyenî (Külekçi, 2005: 142). La timutim nê înterjeksîyonî nêbenî. Ge-ge bêînan zî nîda virazîyeno (Selçuk, 2017: 1042). Mewlidê Xasî de zî no huner şuxulîyeno:

“ey bırā-yı dīnì tım gūş-dāri bìi” (34)

“henkī nān ū șōle zì rūne birā" (35)

“nā dünyā hem mekkede ey 'āşskāān” (35)

"bes niyō hendī çı yaāci āy fetā" (38)

"gō bıbō zey meşk perçe āy bırā" (39)

"ỵā bıbe aḥmed hemā şāh-i vedūd" (40)

“bacdi cū ỵā ey ḳalem nuştış bıke” (43)

"ḩālıḳiṿā bes te’eddeb yā ḳalem” (44)

“ḳaybi ibn-i ādemī ey ins ū cinn” (45)

“ṿā selām hem ‘aleyke ya re īis" (53)

“āminā bermā $\bar{u}$ ỵā āh ū keser

ỵā zerey mın bìi dīnimī vey lımın" (54)

“secde rā vaḳtu vurişt ỵā rabbenā̄" (56)

“māsivā rā bāş bızāni ey verā" (59)

“ey zì bì şā māzì şā ke rabbenā" (60)

"ỵā huūri rabbi tı zāni ỵīnenī" (60)

“kerd ū ỵātu bire min het āy merām” (61)

"ỵā d1 şūre yā muḥammed hem emīn" (63)

“hālıḳi perde vedārut ū ṿā emīn" (64)

“ger tı bānī fícli mārā āy hudā" (65)

Seke mînakî zî nawnenî Xasî, eserê xo de ca dono hunerê nîdayî. Fekê Xasî, Homa, Amîna, pêxemberî bînan, qeleme, Cebraîlî ra no huner virazîyeno.

\subsection{Husnî Talîl}

Eke nuştox behsê yew hedîse, yew çî biko û semedê înan, semedo raşt ney yewna semedo rind û şaîrane binawno no husnî talîl o (Coşkun, 2007: 168). Kê eserê Xasî de zî raştê no hunerî yenî:

"yā bibe aḥmed hemā şāh-i vedūd

şekli țayrā tậvuse āme vücūd" (40) 
Tawûs, benetî teyran de tewr rindan ra yew a. Tewir tewir rengî aye de est î. Bitaybetî boçikê aye zaf balkeş o. Boçikê aye zaf pîl o û pey yew estetîko pîl virazîyayo. Xasî vono semedê no rindeyî, Pêxember o. Gama ke Homa vono "Bibe Ahmed!" şeklê tawûsî zî yeno wucûd. No semedo raşt nîyo. La Xasî muracatê hunerê husnî talîlî keno û vono semed no yo. No beyt de zî husnî talîl est o:

"secde berd pānc rāy bi ḳaybi sermedī

yō sebeb rā māri pānc farẓi tamām” (41)

Xasî vono hama çîyêk û tu kes xelq nêbîyo, ruhê Pêxemberî xelq beno. No ruh, verê Homayî de panc rey secde keno. Coka muslumanan rê panc wext nimac ferz o. La kê nîşnî hetê dînî ra vacî semed kesîn no yo. Bira, gore bi toy hedîsan verî muslumanan rê pancas wext nimac emr beno. Bedê wexto ke Pêxember şono Mîrac weyra Homayî ra rîca keno û nimac fî̀neno panc wextî. Verê no beytî de zî Xasî vono ruhê Pêxemberî ra çilkî kuwenî war. Nê çilkan ra zî birinc û gule yenî wucûd. No zî yew husnî talîl o. Ewta zî no huner est o:
“sẻ ḥezār ū vist ḥezār $\bar{u}$ zīde çār
vaḳtu yī çılki kū yī rā bì berī
her gō yev bī rūḥı yev peyġamberī” (42)

Gore bi toy hedîsan 124.000 pêxemberî ameyî. Xasî no humare girêdayeno $\mathrm{Hz}$. Mihemedî. Ma verî zî vatibê, ruhê Pêxemberî ra çilkî kuwenî var. Xasî vono yew rey de 124.000 çilkî kuwenî var û nê çilkan ra ruhê 124.000 pêxemberî yenî wucûd. Nê rêzan de zî husnî talîl est o:

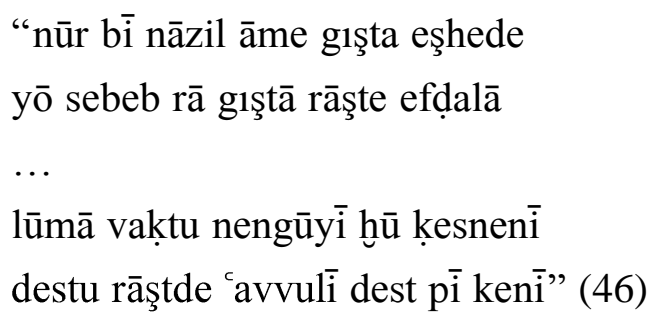

Muslumanîye de desto raşt timutim hîna fazîletin veynîyeno. Coka vacîyeno ke wexto ke muslumanî werd wenî ganî desto raşt bişuxulnî. Hewna wexto ke nenguyanê xo kesnenî ganî desto raşt ra destpê bikî. Xasî vono semedê ney, Âdem o. Çunke Homa nur beno destê raştê Âdemî, gista eşhedî ser. No wext ra bedê Muslumanan ra desto raşt hîna fazîletin beno.

\subsection{Asonans û Alîterasyon}

Nuştoxî semedê ahengî toy herfanê venginan û bêvengan tekrar kenî. Eke herfanê bêvengan tekrar bikî no alîterasyon o. La eke herfanê venginan tekrar bikî no zî asonans o (Durmuş, 2012: 997). Pey no ahenk edebîyat, nêzdî muzîkî beno. Xora hem edebîyatê nuştekî hem zî edebîyatê fekkî yê Zazakî de aheng û muzîkalîte muhîm o (Alay, 2018: 909). Xasî zî muracatê no hunerî keno:

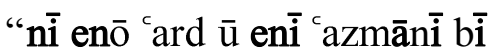




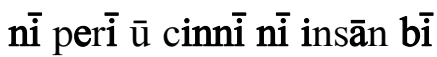

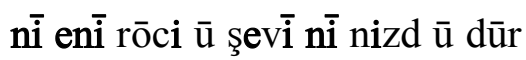 \\ nì zamān nì mekāni bì fütūr" (39)}

Nê beytan de pey venganê "î, e, a," asonans, pey venganê " $n$, b" zî alîterasyon virazîyayo. No aheng şîîrî, nêdzî muzîkî keno. Sewbîna beytan de zî wendox, raştê no hunerî yeno:

$$
\begin{aligned}
& \text { "nāmeyi perdān bi hū yev merḥamet } \\
& \text { yev kerāmet yevzī minnet menzilet" (41) }
\end{aligned}
$$

Wexto ke wendox nê rêzan waneno, goşê ci rê yew aheng yeno. Xasî pey venganê "e" asonans, venganê "m" zî alîterasyon kerdo. Eynî rewşe ewta zî est o:

$$
\text { “rabbenā ỵātı zelemnā her gō hev" (48) }
$$

Na rêze de zî pey venga "e" asonans virazîyayo. Yew asonans zî no ca de est o:

$$
\text { "hem tede est hilāfi kev tamām" (49) }
$$

Eynî hewa no ca de zî pey vengê "e" asonans virazîyayo. Beytê ke cêr de yî de zî nê hunerî est î:

“yev vaḳeyke zerd ū yev sīm hem sè pes

hem deṿey zì zey pesān dāy ende bes

vaḳtu ārde hem yene bī āy şevī

hem receb bī āşme bıbī yev şevī" (52)

Xasî pey vengê "e" yan asonans, vengê "y" zî alîterasyon ardo wucûd. Yew alîterasyon zî ewta est o:

"dār ū ber pīi ū tedir bermāy bi ḥāll" (54)

Pey vengê "r" alîterasyon virazîyayo. Ewta, hunerê asonans est o:

$$
\begin{aligned}
& \text { “ṿā hūuri rabbi tı zāni ṿinenī } \\
& \text {.. } \\
& \text { yi hạattā çavres ṣare kerde tamām" (60) }
\end{aligned}
$$

Rêza yewin de pey vengê "î”, rêza diyin de zî vengê "e” asonans virazîyayo. Seke heme mînakî nawnenî Xasî, Mewlidê xo de hem asonans hem zî alîterasyon şuxulneno.

\subsection{Telmîh}

Nuştoxî ge-ge eseranê xo de behsê qarekterê tarîxî, qarekterê meselan, hedîseyanê tarîxan, mucîzeyan, efsaneyan usb. kenî. Nameyê hunerî ke pey nê çîyan virazîyeno 
telmîh o (Aç11, 2014: 10). No hewa nuştoxî, wendoxan rê yew perspektîfo hera donî. Xasî zî eserê xo de ca dono no hunerî rê:

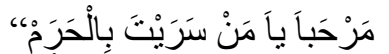

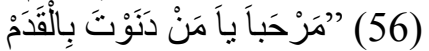

No beyt de Xasî, vîrê wendoxan rê hedîseya Mîracî ano. Pey no îfadeyan hem hedîseya Mîracî rê hem zî sureya Îsra ayeta yewî rê telmîh est o. No ca de zî telmîh est o:

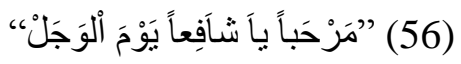

Xasî vono, Pêxember yewmel-wecel (rocê tersî) de şefaatkar beno. Pey qala yewmelwecel qesdê Xasî mehşer o. Yani o, mehşerî rê telmîh keno. No beyt de zî telmîh est o:

“bōrū yō țāsike āvey kevserê̄”” (36)

Pêxember wexto ke şono Mîrac, Cenet de yew çem veyneno. Cebraîlî ra nameyê çemî persono. Cebraîl zî vono nameyê ci Kevser o. Xasî, pey rêza ke cor de ya de hem Mîracî rê hem zî çemê Kevserî rê telmîh keno. Yew telmîho ke no mînval de yo no yo:

$$
\begin{aligned}
& \text { "hậ̣̣̂ılì vaḳtā kō şìi sidre hemān } \\
& \text { hażret-i cibrīīl zìi ev cā bì sekān" (63) }
\end{aligned}
$$

Mîrac de Cebraîl û Pêxember pîya geyrenî. La wexto ke yenî Sîdretu'l Munteha, Cebraîl vono o, nîşno no ca ra vêro. Xasî pey no beyt hem hewna Miracî rê hem zî Sîdretu'l Munteha rê telmîh keno.

Nê çîyan ra vêşêr, Mewlid de nameyê toy şexsîyetê muhîmî yê dînî û tarîxî sey Sidiq, Omer (yew ca de sey Faruk), Osman, Elî (yew ca de sey Kerrarê Sef), Fexrê Razî, Şêx Cuneydî, Âdem, Hawa, Şîs (Şît), Îlyas, Ebdullah, Amîna, Ebdulmuttelîb, Nûh, Hûd, Îbrahîm, Îsmaîl, Musa, Îsa, Meryem, Sara, Asîya vêrenî. Nê nameyê muhîm zî Mewlid de vêrenî: Bedr, Huneyn, koyê Uhud. Pey heme nê nameyan telmîh virazîyeno.

\subsection{Tekrîr}

Eke nuştoxî semedê ahengî û tesîrê vatişê pêt kerdişî eseranê xo de toy çekuyan tekrar bikî tekrîr yeno wucûd. Edebîyatê klasîkî de nuştoxî no huner zaf şuxulnenî. Kê raştê no hunerî Mewlidê Xasî de zî yenî:

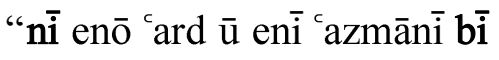

$$
\begin{aligned}
& \text { nì perì ū cinnì nìi insān bì } \\
& \text { nì en⿳亠丷⿵ rōci ù şevī nī nizd ù dūr } \\
& \text { nì zamān nì mekāni bī fütūr" (39) }
\end{aligned}
$$

Xasî nê beytan de çekuyanê "nê, bî" zaf rey tekrar keno. No hewa vatişê xo hîna pêt keno û wazeno wendoxan de yew tesîro pîl bîyaro wucûd. Nê îfadeyan de zî eynî huner şuxulîyayo: 


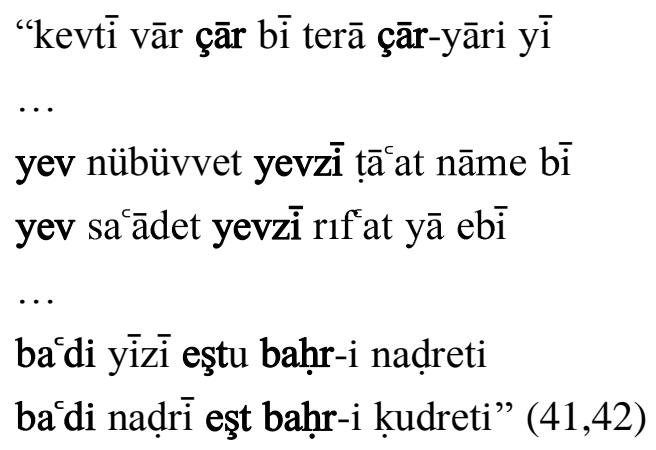

Rêza yewin de çekuya "çar" tekrar beno. Beyto yewin de çekuyê "yew, ẑ̂", beyto diyin de zî çekuya "badê, eşt, behr" tekrar beno. Nê beyt de zî tekrîr est o:

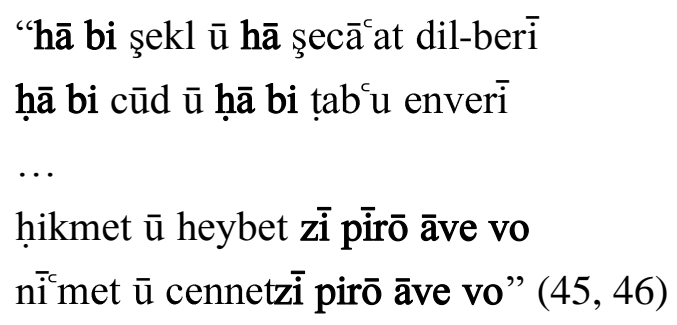

Beyto yewin de îfadeyê "ha, bi" tekrar benî. Beyto diyin de zî “ zî, pêro awe wo" tekrar benî. No hewa hunerê tekrîr virazîyeno. Nê beytan de zî eynî huner est o:

$$
\begin{aligned}
& \text { "müdrike yev yev huzeyme yev kenān } \\
& \text { naḍr } \bar{u} \text { mālik faḩr } \bar{u} \text { gālib zì hemān } \\
& \text { hem lu’ey hem } \mathrm{ka}^{\mathrm{c}} \mathrm{b} \text { ù murre hem kilāb } \\
& \text { hem ḳuṣey zī hōt ū des āmey hisāâ } \\
& \text { yevzì yō 'abdu'l-menāf mürte }{ }^{c} i b \\
& \text { yevzī hâşim yevzīi cabdu'l-mutțalib” (49) }
\end{aligned}
$$

Nê beytan de çekuyê “yew, hem, zî” tekrar benî. Na rêze de zî tekrîr est o:

$$
\text { "berzī ger berzī hemā ez ỵeyşenā" (63) }
$$

Ewta zî çekuya "berzî" tekrar beno. Seke heme mînakî nawnenî Xasî, Mewlidê xo de zaf cayan de muracatê hunerê tekrîrî keno. No hewa hem vatişê xo pêt keno hem zî yew aheng ano wucûd.

\section{PEYNî}

Xasî, mewlidê xo de zafena, babetî ke heya inkey sewbîna mewlidan de zî behs bîyî ser vindeno. Mîsale hamdele zaf mewlidan de est o. Mewlidê Xasî de zî beşa yewin, derheqê hamdele de yo. Heto bîn ra, Pêxemberî rê selat û selam ardiş, zafê mewlidan de est o. Xasî zî beşanê mewlidê xo pey "vāzeni ger mā hualāṣiyyā tamām / yaātışi mā eṣșalāt ū ve's-selām" girêdayeno. Mewlidan de peynî de beşa dua rê ca dayîş muhîm o. Xasî zî peynî eserê xo de ca dono duayî rê. Nê çîyan het, mewlid de babetê tertîbê û 
fadlê wendişê mewlidî; xelqê Pêxemberî û eşyayan; xelqê Âdemî; Âdemî Cenet ra eştiş; zewacê maye û pîyê Pêxemberî; mucîzeyî ke Amîna ciwîyayî; bîyayîşî Pêxemberî; mucîzeyî ke roco Pêxemberî ameyo dinya de ameyî wucûd; nuzulê wehyî; hedîseyê Mîracî ser vindirîyeno.

Hetê hunerê edebî de zî eserê Xasî serkewte yo. Xasî, eserê xo de zafê hunerê edebîyan şuxulneno. No hewa hem hetê edebî ra eserê xo aver beno hem zî hînterlandê ci hera keno. Mîsale pey hunerê telmî' Xasî, sewbîna ziwanan dekeno eserê xo. Pey şuxulnayîşê ebced û tarîx fînayîşî zî qismêk matematîkî eser de xo rê ca veyneno. Pey hunerê îktîbasî zî Xasî, wendoxan beno dinyayê Qur'an û hedîsan. Hunerê cînas, asonans, alîterasyon, tekrîr de zî o, wendoxan nizdî muzîkalîte keno. Xasî, hunerê îstîfham û nîda de wendoxan keno zereyê kelecano ke o ciwîyeno. Hunerê telmîh de wendoxî, berê vîyarte, tarîxî ra vêrenî toy hedîseyan, şexsan veynenî. Xasî hunerê mecazo mursel, teşbîx, îstîare, teşxîs û întak, leff û neşr, îade, îştîkak, husnî talîl de zî şexsîyetê hunermendîyeyê xo zelal keno.

Heme nê çî nawnenî ke Xasî, pey mewlidê xo edebîyatê Zazakî resneno sewîyeyê edebîyatê bînan. Her çiqas no mewlid, edebîyatê Zazakî de esero nuştekîyo verin bibo zî Xasî, pey hunermendîyeyê xo yo serkewte edebîyatê Zazakî, yew hemle de dekeno zereyê edebîyatê serkewtan.

\section{ÇIMEYî}

Açıl, Berat. "Telmih'e Telmih: Klasik Türk Edebiyatında Geleneğin İnşası”. Erdem 67 (2014): 5-18.

Aktaş, Hasan. Modern Türk Şiirinde Edebî Sanatlar. Konya: Çizgi Kitabevi, 2002.

Alay, Okan. "Sözlü Kültür Bağlamında Zazaca (Kirdkî) Şiirsel/Ezgili Anlatım Geleneği: Ozanlık-Deyîrbazlık-Dengbêjlik". e-Şarkiyat İlmi Araştırmalar Dergisi 10/3 (2018): 903-920.

Anter, Musa. Hatıralarım. İstanbul: Avesta Yayınları, 2000.

Bursevî, İsmail Hakkı. Rûhu'l Beyân, C. 1. İstanbul: Erkam Yayınları, 2010.

Coşkun, Menderes. Sözün Büyüsü/Edebî Sanatlar. İstanbul: Dergah Yayınları, 2007.

Çetin, Nurullah. "Edebî Sanatlar". Edebiyat Bilgi ve Kuramları. Edt. Zeliha Güneş. 200226. Eskişehir: AÖF Yayınları, 1998.

Dağılma, İbrahim. “Ahmedê Xasi'nin Hayatı ve Mewlid Adlı Eserinde Tema”. Bingöl Üniversitesi Yaşayan Diller Enstitüsü Dergisi 1/1 (2015): 124-146.

Demir, Musa. “Bat1 'Metafor'u ve Doğu ‘İstiare'sinin Mukayeseli Olarak İncelenmesi”. Türkbilig 18 (2009): 64- 90.

Durmuş, Mustafa. "Klasik Osmanlı Nesrinde Aliterasyon". Turkish Studies International Periodical For The Languages, Literature and History of Turkish or Turkic 7/1 (2012): 995-1004. 
Eliaçık, Muhittin. "Bazı Belagat Kitaplarında Mecâz-ı Mürselin Tanım ve Tasnifi Üzerine Bir Karşılaştırma". Turkish Studies - International Periodical For The Languages, Literature and History of Turkish or Turkic 8/9 (2013): 37-47.

Elker, Salâhaddin. "Kitâbelerde Ebced Hesabının Rolü”, Vakıflar Dergisi 3 (2006): 1727.

Hasi, Ahmed-i. Mevlid. Haz. Osman Özer. Bingö1: Bingöl Üniversitesi Yayınları, 2016.

Haşıc1, Duygu. Klasik Şiir Öğretiminde Yapısal Olarak Leff ü Neşr Sanatından Yararlanma. Yüksek Lisans Tezi, Dokuz Eylül Üniversitesi, 2010.

Kocabıyı, Halil İbrahim. "İstifhâm Edatları”, Bilecik Şeyh Edebali Üniversitesi Sosyal Bilimler Enstitüsü Dergisi 2 (2017): 649-663.

Kocakaplan, İsa. Açıklamalı Edebî Sanatlar. İstanbul: Türk Edebiyatı Vakfı Yayınları, 2005.

Korkusuz, M. Şefik. Tezkire-i Meşayih-i Amid, Diyarbekir Velileri I, II. İstanbul: Kent Yayınları, 2004.

Kur'an-ı Kerîm Meâli. Haz.: Halil Altuntaş, Muzaffer Şahin. Ankara: Diyanet İşleri Başkanlığı Yayınları, 2011.

Külekçi, Numan. Açıklamalar ve Örneklerle Edebî Sanatlar. Ankara: Akçağ Yayınları, 2005.

Xasî, Ehmedê. “Mewlidê Nebî”. Açarnayox: M. Malmîsanij. Hêvî 4 (1985): 75-111.

Xasî, Ehmedê. Mewlûdê Nebî. Açarnayox: Mihanî. Îstanbul: Weşanxaneyê Frrat, 1994.

Xasî, Ehmedê. Mewlîd. Açarnayox: W. K. Merdimîn. Îstanbul: Weşanxaneyê Hîvda, 2008.

Xasî, Ehmedê. Mewlidê Kirdî. Açarnayox: Roşan Lezgîn. Îstanbul: Weşanxaneyê Nûbihar, 2013.

Lezgîn, Roşan. Ferhengê Termanê Edebîyatî. Dîyarbekîr: Nameyê Weşanxane Nênusîyayo, 2017.

Özkan, Mustafa. "İrhâsâtla İlgili Rivâyetlerin Metin ve Anlam Açısından Değerlendirilmesi”. Şırnak Üniversitesi Ilahiyat Fakültesi Dergisi 14 (2016): $14-41$.

Pala, İskender. Ansiklopedik Divan Şiiri Sözlüğ̈̈. İstanbul: Kapı Yayınları, 2005.

Selçuk, Bahir. "Klasik Türk Şiirinde Nida". Atatürk Üniversitesi Türk Dili ve Edebiyatı Araştırmaları/Makaleler. Edt. Lokman Turan ve Oğuzhan Sevim. 1040- 1052. Erzurum: Atatürk Üniversitesi Yayınları, 2017. 
Varol, Murat. "Zazalarda Mevlid ve Siyer Geleneği”. II. Zaza Tarihi ve Kültürü Sempozyumu Bildiri Kitabı. Edt. Murat Varol. 625-654. Bingöl: Bingöl Üniversitesi Yayınları, 2012.

Yergin, Mehmet. "Mewlidê Mela Ehmedê Xasî de Tesîrê Mewlidê Mela Huseynê Bateŷ̀”, International Journal of Kurdish Studies 1 (2015): 98-109. 